\title{
Clinique ToGo:
}

\section{Changing Legal Practice in One African Nation in Six Days}

\author{
Stephen A. Rosenbaum*
}

\section{Chers confrères, Chères consoeurs, ${ }^{1}$}

With honour and humility I accepted an invitation from the U.S. State Department to participate as a technical advisor in a weeklong rule of law ${ }^{2}$ seminar in Togo, with attorneys, judges, law professors and students. My mission was to explain various models for delivery of free legal services and assist in developing proposals for establishing a bar association pro bono ${ }^{3}$ programme

* Lecturer, University of California, Berkeley School of Law; Adjunct Professor, Golden Gate School of Law; and Chercheur Associé, Université d'Artois, Faculté de Droit. Mr. Rosenbaum is a periodic recipient of U.S. State Department Speaker Specialist grants and coordinator of the Francophone Africa Law Project (FALP). In 2011-12, he is serving as a Legal Education Advisor to the American Bar Association Rule of Law Initiative in Cairo, Egypt and Doha, Qatar. The author is indebted to Miliette Marcos, FALP Project Attorney, for her invaluable research assistance and editorial suggestions, and to Judge Paul Fogel, Ret., who introduced him to the Speaker Specialist Program. He also thanks Savannah Blackwell, J.D., Berkeley Law, Class of 2010, for research assistance on an earlier draft. An abbreviated version of this article was published in 6 Publicist (Berkeley Journal of International Law) (2010), on-line journal, http://bjil.typepad.com/publicist/vol-6-fall-2010/.

1 This is the traditional French salutation made to audiences in seminar or conference settings, after greeting the "Honorables Invités." Its translation seems to lie somewhere between "Dear Colleagues," "Dear Comrades" and "Dear Brothers and Sisters."

2 Rule of law (ROL) programmes have been conducted in newly "democratic" countries by governmental, nongovernmental, inter-governmental and private agencies. In David Tolbert \& Andrew Solomon, United Nations Reform and Supporting the Rule of Law in Post-Conflict Societies, 19 Harv. Hum. Rts. J. 29, 30-33 (2006), two international jurists provide a definitional framework and application of a term that refers to core elements of judicial and legal reform: "Despite the ubiquity of its usage and the importance of the idea, the rule of law, much like the concepts of 'justice' or 'transitional justice,' is endowed with 'a multiplicity of definitions and understandings' ... and " ' is not a recipe for detailed institutional design [but] an interconnected cluster of values.' (citing Professor Gerhard Casper).” Id. at 31.

3 An abbreviation of pro bono publico, this term refers to legal services performed voluntarily and without payment as a public service. It is derived from Latin, meaning "for the public good". Black's Law Dic. (9th ed. 2009) Volunteer legal services may go by other names. For example, in South Africa, the term is pro amico, see infra note 38, and in Lesotho, it is pro deo counsel. Adam Stapleton, Introduction and Overview of Legal Aid in Africa, in Penal Reform Int'l and Bluhm Legal Clinic, Access to Justice in Africa and Beyond 13-16 (Nw. U. Sch. of L., ed. 2007) (hereafter Access to Justice in Africa 3, 14. “...[F]or the Christian lawyer, the issue is not so much about pro bono aspirations or improving our professional image. It's more about the pro Deo duty we owe to God." Christian Legal Society. http://www.clsnet.org/legal-aid/programs/pro-bono-pro-deo-or-both. (last visited 12 Oct. 2009). 
in conjunction with the nation's principal law school. ${ }^{4}$

When the State Department first invited me to participate in its speaker specialist programme, I admit that for me it was all about having a glimpse of an otherwise inaccessible part of the world and the attendant cultural, professional and intellectual exchange. ${ }^{5}$ Only after my initial programme visit did I become familiar with the concept of "rule of law" (l'état de droit), as well as the related concepts of access to justice and the law and development movement. ${ }^{6}$ This was to be the focus of my journey to Togo.

Beyond expressing a desire to discuss this general theme, no one at the State Department or the Embassy in Lomé, Togo explicitly informed me at the time of the invitation about the rationale for the seminar, its timing or how it corresponded to foreign policy or public diplomacy objectives in West Africa. While this seemed like a lot to accomplish in one week, the scenario was consistent with my experience on earlier sojourns.

Typically, the consultant's scenario is broadly sketched by the embassy public or cultural affairs attaché. These diplomats assume that American jurists have something of interest to say to our counterparts in developing democracies and that this is accomplished by a series of lectures or informal visits in small groups.

In Togo, the Embassy had reason to believe that the overall theme of legal aid to the indigent, particularly as it involved clinical legal education and pro bono service, was suitable for a programme speaker. Whether the suitability was informed by discussions with the Togolese or by what was in vogue with Foreign Service colleagues in other African capitals or Washington, DC, I do not know. I was not given any background documentation beyond the standard State Department country report.

4 The Project was funded by the U.S. Department of State, which awarded me a U.S. Speaker and Specialist Grant through its International Information Programs division. Letter of 24 May 2007 (on file with author). For an account of a part-time ROL speaker who has obtained personal satisfaction and professional success, see, Amelia Hansen, The Missionary: It's His Calling, Calif. Lawy. 20 (Aug. 2009). Judge Clifford Wallace of the Ninth Circuit Court of Appeals has been speaking and consulting for a number of years in Asia, the Middle East, Pacific Islands and Africa. He quips: "No one will remember my [judiciall opinions. But I think they will remember my contributions abroad." Id. at 22.

5 I had previously lectured in other French-speaking African states on such themes as judicial independence, human rights and alternative dispute resolution. See, e.g., Stephen A. Rosenbaum, Supporting Democracy: Senegal Needs U.S. Help as it Races to Reform Juridical Institutions, DAILY J.(27 Sept. 2000). Since 2000, I have been awarded eight grants for rule of law projects in francophone Africa, viz., Senegal, Guinea, Chad, Central African Republic, Togo and Cameroon.

6 It appears that I am in good company in my ignorance. See, Leah Wortham, Aiding Clinical Legal Education Abroad: What Can Be Gained and the Learning Curve on How to Do So Effectively, 12 Clin. L. Rev. 615, 617 (2006) (confessing unfamiliarity with Law and Development Movement (LDM) scholarship until far into her experience with clinical education outside the United States). Scholar Erik Jensen cites several works "[f]or those who are interested in the great historical debates about the definition of rule of law." Erik G. Jensen, Justice and the Rule of Law, in Charles T. Call, Ed., Building States to Build Peace (2008) 138, n. 16. See also, Ryan S. Lincoln, Rule of Law for Whom? Strengthening the Rule of Law as a Solution to Sexual Violence in the Democratic Republic of the Congo, 26 Berkeley J. Gender, L. \& Just. 139, 150, 160 (2011) for a discussion of "thin" and "thick" definitions. The term "is notoriously difficult to define, and often means different things to different people. Many approach the rule of law from a visceral perspective, what Jane Stromseth calls the problem of 'I know it when I see it."' (quoting Jane Stromseth, David Wippman \& Rosa Brooks, Can Might Make Rights?: Building The Rule of Law After Military Interventions 56 (2006)). Id. at 150. 
It was through my perusal of the relevant literature that I assumed the immediate need for legal aid was among prison detainees. Only after arrival in Togo did I learn that the nation had an inoperative legal assistance statute that had been on the books for decades. The statute, Ordonnance No. 70-35, Article $10^{7}$ provided legal aid to the indigent but required the executive to issue an implementing decree. The legal community had also crafted a recent judicial modernisation plan. I was also informed, once in Togo, about a new cooperation agreement between the principal law school and largest local bar association. In addition to this administrative framework, there existed an informal pro bono effort by members of the bar to make ad hoc visits to the prison to obtain some releases. These efforts represented the totality of the Togolese indigent legal services programme.

The United States supports democratisation efforts in countries like Togo, which are transitioning from autocratic one-party states with under-developed judicial procedures. Typically, the American government contributes its resources to nations which display a modicum of stability and targets a mid-level elite receptive to reform. Given its history of political and electoral abuse and violence, ${ }^{8}$ Togo was not well placed to request financial or material aid from foreign governments or non-governmental sources at the time of my impending visit. ${ }^{9}$ Nonetheless, the on-site diplomatic corps endorsed an initiative to address the lack of a genuine legal assistance scheme and to improve Togolese citizens' access to justice. There was a lot of hope riding on the upcoming elections.

In this diary cum essay, I describe (1) the background for the visit, (2) the series of exchanges with my hosts, (3) the objectives and means for structural change in the spheres of education and practice, and (4) the Togolese legal and political culture. The image of "Cook's tour" 10 or "summer vacation" 11 applied to the visiting consultant needs to be laid to rest. I hope, instead, to capture some of the flavour of the experience, reflect on the capacity of short-term consultants to have an impact on legal reform, and offer some advice for those who are similarly engaged in ROL support and solidarity activities. ${ }^{12}$

7 Organisation Judiciare Ordonnance No. 78-35, art. 10 (09/07/78) in Journal Officiel de la République Togolaise (No. 21 (bis) 11 Sept. 1978)).

8 The violence in Togo had not totally abated. See, e.g., U.S. Dep't of State, Country Reports on Human Rights Practices (Mar. 8, 2006)

9 The Bureau of Consular Affairs' succinct, unflattering (and constant) description reads: "Togo is a small West African country with a stagnant economy in a state of political uncertainty." http://travel.state.gov/travel/ cis_pa_tw/cis/cis_1041.html\#country. (last visited 15 July 2010).

10 Commentators first applied this term in the late 1960 s to the short stints at African universities made by American law professors "arriv[ing] in foreign territory unencumbered by any significant understanding of the local language, law, polity, economy, or culture.” Kirsten A. Dauphinais, Training A Countervailing Elite: The Necessity Of An Effective Lawyering Skills Pedagogy For A Sustainable Rule Of Law Revival In East Africa, 85 N.D. L. Rev. 53, 72 (2009)(citations omitted). Professor Dauphinais is mindful that not every expert who visits [East] Africa can stay long term. Still, "the Western law professor involving him or herself in this process must nurture an ethos the opposite of cut and run." Id. at 105.

11 Professor Richard Wilson refers to the "how I spent my summer vacation developing clinics in [insert developing country name here]" phenomenon. Richard J. Wilson, Western Europe: Last Holdout in the World-wide Acceptance of Clinical Legal Education, 10 German L.J. 823, 823 (2009) (brackets in original).

12 Self-criticism is still in order. I must neither become (nor be perceived as) just another privileged overseas traveler - a charge that can be leveled against the legal elites in the countries I visit when they travel abroad in "study tours." See infra note 132. As for the "privileged" part, one disability rights colleague characterizes these visits as "grueling" and underpaid. (Telephone Conversation with P.B., 11 Aug. 2010). 


\section{Préparations}

The scope of the programme had been defined broadly with a focus on the mechanisms for reform. Thus, as was the case with my previous visits to other countries, I was free to exercise virtually independent judgement about the project format and the content of my remarks. It was important to me that I not be viewed as yet one more speaker on the circuit-much less the Great White Saviour - jetting in and out, offering standard bromides for reform. ${ }^{13}$ A criticism of "access-tojustice" or ROL programmes is their failure to "overcome transplant, formalist, and prescriptive criticisms of the 1960s law-and-development movement..."14 This failure is most acute where the justice system is inoperative in rural areas or for poorer citizens. Such methods have also been less effective where justice is obtained through informal dispute mechanisms, social movements, or political struggle. ${ }^{15}$ Modern programmes have evolved, however, and are distinguished by three characteristics: the involvement of practitioners (in addition to academics); participation of multinational actors, together with those from the United States; and an effort to work in partnership with African educators and practitioners to develop suitable institutions. ${ }^{16}$

The programme in Togo harnessed the effectiveness of this last change, in particular.

Direct communication with embassy staff is essential. I immediately contacted the relevant

13 What comes to mind is the image of former Treasury Secretary, university president and presidential advisor Lawrence Summers, who reportedly “'blew into Jakarata for a few hours,' after which he climbed the stairs to his plane, looked out over the unwashed, and said, 'Indonesia needs the rule of law."' Jensen, supra note 6 at 122.

14 Jeremy Perelman, The Way Ahead? Access-to-Justice, Public Interest Lawyering, and the Right to Legal Aid in South Africa: the Nkuzi Case, 41 StanFord J. INT'L L. 357, 398 (2005) (footnote omitted). For a discussion of the rationale and criticism of ROL programmes, see generally, Erik G. Jensen, The Rule of Law and Judicial Reform: The Political Economy of Diverse Institutional Patterns and Reformers' Responses, in BEYOND COMMON KNOWLEDGE: Empirical Approaches to the Rule of Law 336, 348 (Erik G. Jensen \& Thomas C. Heller, eds., 2003); See also Thomas Carothers, Aiding democracy abroad: The Learning Curve 164 (1999) and Jensen, supra note 6. For an overview of ROL and LDM critiques, as seen through the lens of a clinical law professor, see Wortham, supra note 6 at 632-53. With regard to early investment in post-liberation African legal education and leadership development, see Thomas F. Geraghty \& Emmanuel K. Quensah, African Legal Education: A Missed Opportunity and Suggestions for Change: A Call for Renewed Attention to Neglected Means of Securing Human Rights and Legal Predictability, 5 Loy. U. CHI. InT'L L. Rev. 87, 88-89 (2007) See also, Dauphinais, supra note 10 at 55-80 (history and criticism of LDM in East Africa). "AAmerican legal assistance was characterized in part by a rather awkward mixture of goodwill, optimism, self-interest, arrogance, ethnocentricity, and simple lack of understanding. . . . [T] he law and development movement was . . f flawed and rather inept . . .,' displaying a 'missionary spirit."' Id. at 73 (quoting James Gardner, Legal Imperialism: American Lawyers and Foreign Aid in Latin America 4-5, 13 (1980).)

15 Perelman, supra note 14 at 398. (footnote omitted).

16 "Culturally-competent collaboration" should be the aim of every visiting consultant, whatever length the visit. It is the mantra of everyone who has taught and thought about this subject. See, e.g., Geraghty \& Quensah, supra note 14 at 88, Wortham, supra note 6 at 640, Dauphinais, supra note 10 at 103-06, and Peggy Maisel, The Role of U.S. Law Faculty in Developing Countries: Striung for Effective Cross-Cultural Collaboration, 14 CLIN. L.REV. 465, 496-97 (2008). One commentator writes: "The setting for today's law and development [movement] is quite different...the consensus is far stronger in favor of reform and the legal approaches identified with the United States, including the core idea of a strong and independent judiciary. Lawyers do not have to fight for their role this time. Economists have come to see the importance of legal institutions to the markets that they now promote [footnote omitted]." Bryant G. Garth, Building Strong and Independent Judiciaries Through The New Law and Development: Behind The Paradox of Consensus Programs And Perpetually Disappointing Results, 52 DePAUl L. REV. 383, 385 (2002). However, Dean Garth notes that the legal reform initiative process "is a hegemonic one that focuses on the business of exporting and importing [by power elites] on debates and issues that have salience in the north (here in the United States) at a particular time and place. We export our own palace wars" Id. at 395-96). 
personnel in Togo and was able to correspond frequently by email with the Political Affairs Officer (PAO) and her assistant. Neither had a background in law. Both were generalists responsible for a number of portfolios in a small embassy. Since they were deferring to the local bar association for programmatic detail and leadership, the Embassy was either hesitant, or unable, to provide all the information needed to refine the topic, gauge expectations and determine logistics. My attempts to communicate directly with the bar association, however, were frustrated both by poor Internet connection ${ }^{17}$ and a lack of detail in the information the association sent my way. Despite my difficulties with communication, it became apparent that the two broad objectives for the Togolese were: (1) develop a bar association pro bono programme to facilitate delivery of legal aid to the indigent; ${ }^{18}$ and (2) establish a clinical education component at the capital's law school. ${ }^{19}$

It is now standard advice that the visiting legal educator or consultant prepare by immersing herself in the law, customs and culture of the country of destination before arrival. ${ }^{20}$ One should expect no less of the very short-term visitor-even if the guest's preparatory efforts are not reciprocated by the hosts. ${ }^{21}$ In my case, the overall agenda was clear about the request for technical assistance. However, there was no specification of the pressing legal need to be met by this aid. I took it upon myself to fill in the gaps. The literature suggested that unnecessary pretrial detention and prison conditions would be a priority. Togo, like many other African nations, had a history of detaining its citizens for unwarranted periods of time, and in overcrowded and unsanitary conditions. ${ }^{22}$

To ensure access to justice in Togo, it was essential to first understand what the existing system

17 Internet communication outside the embassy can be problematic. To minimize interrupted or delayed service, many professionals have a United States- or France-based email address (e.g., <yahoo.com> or <yahoo. $\mathrm{fr}>$ ). However, their use of email may be limited by power outages, lack of computer access or customary correspondence practice. The heavy reliance on email exchanges for business correspondence that we have come to know in the United States has not taken hold in most of Africa.

18 For a history of free legal aid services in the United States and the intersection with international human rights law and procedures, see generally, Stephen A. Rosenbaum, Pro Bono Publico Meets Droits de l'Homme: Speaking A New Legal Language, 13 Loyola L.A. Int'l \& Comp. L. J. 499 (1991). See also Access to Justice in Africa, supra note 3 at 13-16 (analysing difficulties concerning pro bono schemes in Africa).

19 For a brief discussion of legal aid clinics in Africa, see David McQuoid-Mason, The Supply Side: The Role of Lawyers in the Provision of Legal Aid - Some Lessons from South Africa, in Access to Justice in Africa, supra note 3 at $111-113$. See also, Carothers, supra note 14 at $167 \& 169$ (noting that legal education may also be a focus of US aid providers).

20 See, e.g., Maisel, supra note 16 at $492-94$ and Dauphinais, supra note 10 at 103-05. Professor Stuart Cohn writes: "As obvious as this recommendation appears, I have been told in more than one country of visiting 'experts' who arrive knowing practically nothing about where they are, and who deliver set lectures that barely, if at all, touch local concerns. It does not matter how technical the subject matter: an instructor's failure to know local laws, history, and culture undermines the effectiveness of the presentation." Stuart R. Cohn, Teaching in a Developing Country: Mistakes Made and Lessons Learned in Uganda, 48 J. Legal Educ. 101, 107 (1998). These visitors "are engaging, even if they do not realize it, in a form of anthropological encounter." Maisel, supra note 16 at 495 (quoting University of Malta Senior Law Lecturer David Zammit).

21 This point was brought home to me just a few days before my departure for Togo when I attended a San Francisco bar association presentation by Stephen Mansfield, one of the first prosecutors at the International Criminal Tribunal for Rwanda. Mansfield related that when he had arrived in Kigali years earlier for an undertaking much more ambitious and consequential than my upcoming workshops, he found there had been almost no preparation by the embassy or local authorities. Stephen Mansfield, "War Crimes Investigations \& Tribunals: Lessons from Cambodia \& Rwanda," San Francisco Legal Aid Society (25 Sept. 2007).

22 See, e.g., Yao Dzidzinyo Claude Bouaka, Garanties des Droits des Détenus au regard des Articles 7, 9 et 10 du Pacte International relatif aux Droits Civils et Politiques: Une Analyse Juridique de la Situation des Droits de l'Homme au Togo (Verlag 2003) and U.S. Dep't of State, Country Rep. on Hum. Rts. Practices - Togo (25 Feb. 2009), avail. at http://www.state.gov/g/drl/rls/hrrpt/2008/af/119029.htm. (last visited 15 July 2010). 
provided. Exercising my own initiative about the nature and scope of the assignment led to library and Internet research. The irony was that I was probably better positioned than my prospective Togolese hosts to access the texts which are fundamental to reforms in African legal education and practice of law. Whether due to the cost of printing, or transportation and communication obstacles, the very codes, reported appellate decisions and international accords on which African jurists rely actually may be unavailable to the judges and lawyers themselves. ${ }^{23}$ During an earlier State Department visit to Guinea, for example, I discovered a curious collection in my hotel gift shop: copies of legal codes on the bottom of a display case, mingled with local crafts and trinkets. While these "goods" were being offered to tourists, Guinean judges bemoaned their lack of access to legal materials.

My research ${ }^{24}$ fell into three main topical areas: approaches to clinical education ${ }^{25}$ with an emphasis on developing countries; ${ }^{26}$ model civil law statutes for free legal services delivery; and reform campaigns aimed at reducing prison populations. ${ }^{27}$ Email exchanges with embassy contacts from an earlier visit to Senegal, visits to websites operated by prison reform advocates and Frenchlanguage jurists, ${ }^{28}$ and materials housed in the Boalt Hall ${ }^{29}$ law library ${ }^{30}$ formed the bulk of my research.

23 Professors Geraghty and Quensah, supra note 14 at 90, describe in graphic terms how "African law schools are starving," and no less so when it comes to library collections, legal information, technology and (updated and relevant) course books. Id. at 90, 97-99, 102. Professor Dauphinais also writes about insufficient quantities of local statutes and other legal materials amongst students and lawyers. Although their articles focus on law schools in African Commonwealth nations and Ethiopia, the analyses and recommendations from Geraghty and Quensah and Dauphinais are equally apt in francophone Africa. Dauphinais, supra note 10 at 104.

24 Only after my trip did I discover some of the most insightful and useful articles on topic - some of which had not yet been written.

25 "Clinical education" encompasses many meanings, ranging from "in-house, live-client" settings in law schools to field placements or externships to simulation classes. AALS Section on Clinical Legal Education, Clinicians' Desk Reference (Apr. 2009), n. 2. "Applied legal education" may be a more useful term insofar as it describes "a reflective and experiential learning process without the economic and efficiency pressures of the workplace, to help students understand how the law works in action while providing sorely needed pro bono representation to the poor." See, Center for the Study of Applied Legal Education, http://www.csale.org/need.html (last visited 9 Aug. 2010).

26 See, Richard J. Wilson, Three Law Schools in Chile, 1970-2000: Innovation, Resistance and Conformity in the Global South, 8 Clin. L. Rev. 515, 517 n.5 (2002) on the term "global south" in lieu of what he deems to be the more pejorative and imprecise "developing" country or "Third World."

27 See Paddington Garwe, Developments in Penal Reform in Africa, in Access to Justice in Africa, supra note 3 at 33-35. Interestingly, "[p]risons have not been a target of U.S. rule-of-law assistance, despite the horrendous state of prisons in most transitional societies and governments' interest in receiving external aid to improve them." Carothers, supra note 14, at 167. According to Carothers, founder and director of the Carnegie Endowment's Rule of Law Project, the potential for criticism from Congress or human rights groups "has scared away most U.S. officials." Id.

28 L'association des des cours judiciaires francophones, for example, maintains a website, www.ahjucaf.org (last visited 9 Nov. 2011) and reference materials on court-related developments in the francophone world.

29 The law school has since been re-branded as "Berkeley Law." See University of California Berkley Law, Memorandum from Dean Christopher Edley (24 Apr. 2008), avail. at http://www.law.berkeley.edu/identity/ edley-letter.html (last visited 19 Dec. 2010). However, references to its former name are still permitted, at least in-house, notwithstanding the new name and public image. Id.

30 The library has small collections on African human rights and Togo. Surprisingly, the Togolese Constitution circulates for only one week, even for faculty. Fortunately, I was granted an extension. It is ironic that the Constitution was probably more readily available (and in demand) in the U.S. than Togo. 
My contacts at the Global Alliance for Justice Education (GAJE) ${ }^{31}$ provided a referral to Thomas Geraghty, the Associate Dean and Director of Northwestern University's Bluhm Legal Clinic. The Clinic had recently helped to facilitate a conference on African legal aid in the criminal justice system, organised by Penal Reform International. ${ }^{32}$ Professor Geraghty ${ }^{33}$ was kind enough to quickly ship copies - in English and French - of a just published collection of detailed papers presented at that conference.

A clinical attorney affiliated with Stanford Law School, who had helped establish a community law clinic in Ghana, ${ }^{34}$ provided some sample interview simulations that she used with her students before they departed for a mini-semester in Accra. I was considering introducing my Togolese workshop participants to simulation exercises, should the opportunity present itself.

Lastly, a pro bono specialist ${ }^{35}$ described for me the workings of a sophisticated computerised network of U.S.-based firms. These firms are matched with legal services and public interest lawyers in search of co-counsel or for referrals on matters they are unable to handle. ${ }^{36}$ Of course, to be of value would require adapting this concept to a country where a six lawyer cabinet constitutes a

31 Law teachers, judges, legal practitioners and activists from five continents convened in 1996 to form an organisation to promote "socially relevant legal education." With members from over 50 countries, GAJE facilitates cross-national educational exchange programs and joint research projects. Its goals include support for "innovative justice education, especially in developing countries" and serving as a teaching methodology and materials clearinghouse. http://www.gaje.org (last visited 26 June 2010). For more about GAJE and the building of a worldwide movement to "advanc[e] the cause of justice through legal education," see Frank S. Bloch, Access to Justice and the Global Clinical Movement, 28 Washington Univ. J. L. \& Pol'y 111, 131-38 (2008).

$32 \mathrm{PRI}$ is a NGO working in partnership with governments on penal and criminal justice reform throughout the world, including the development and implementation of human rights instruments relating to prison conditions and reduction in the use of imprisonment. http://www.penalreform.org (last visited 12 July 2010). It was the chief sponsor of a conference, attended by researchers and practitioners from 21 African countries, held in Lilongwe, Malawi, in November 2004. A conference drafting committee produced the Lilongwe Declaration on Accessing Legal Aid in the Criminal Justice System in Africa and a Plan of Action. The Committee was chaired by Malawi's Justice Rezine Mzikamanda. Professor Geraghty served as the only non-African member of the Committee and Northwestern University law students supported the work with their note-taking. The Declaration and Plan of Action are reprinted in Access to Justice in Africa, supra note 3 at 39-50.

33 I later learnt that Professor Geraghty has an interest and expertise in African legal education, a field in which the Bluhm Center's international human rights students have been active. See, generally, Geraghty \& Quensah, supra note 14 .

34 Danielle Jones, Supervising Attorney, Stanford Community Law Clinic. The Stanford Community Law Clinic serves low-income clients in and around East Palo Alto on mostly employment, housing and criminalrecord-clearance matters. Stanford Community Law Clinic, http://www.law.stanford.edu/program/clinics/ communitylaw/ (last visited 12 July 2010).

35 Julia Wilson, Executive Director, Legal Assistance Association of California. LAAC is an organisation of nonprofit legal services that assists and strengthens its members in their work providing legal assistance and equal access to justice to low-income Californians. http://www.calegaladvocates.org/ (last visited 13 Mar. 2009).

36 Id. See also Pro Bono Institute, http://www.probonoinst.org/ (last visited 13 Mar. 2009). 
large firm ${ }^{37}$ and where there is no real pro bono ${ }^{38}$ tradition, much less a codified ethical standard for representing the unrepresented. ${ }^{39}$ In addition, the structural benefits of a United States pro bono operation, such as furnishing malpractice insurance or training in specialized practice areas, would be irrelevant in the typical West or Central African setting.

However, the specialist's other advice about establishing a legal services or clinical office made perfect sense, notwithstanding the smaller scale and less developed legal infrastructure: (1) Begin with a small pilot project; (2) Select an advisory board; (3) Establish a protocol for case acceptance and attorney or professor oversight; (4) Form partnerships with other lawyers, judges and NGOs; and (5) Conduct an evaluation after a fixed period of time. As for concerns about infrastructure, it would be, in large part about the physical and material aspect. ${ }^{40}$ Not surprisingly, lack of funding and staffing is a huge obstacle for legal clinics in developing countries. ${ }^{41}$

My investigation had thus equipped me with the basic Constitutional text; statutes from neighbouring nations; reports on Togolese politics, African legal reforms and prison conditions; and press clippings. Armed with this information, I came to understand the expansive scope of the project. Email exchanges in the weeks just before departure confirmed the mission was overly ambitious: a three day conference to (1) draft a statute establishing free legal services for the poor; and (2) design a clinical legal education programme at the University of Lomé faculty of law. Again, it was important to avoid an in-and-out visit complete with a one-size-fits-all reform agenda.

Conference work was to occur in small groups, book-ended by formal plenary sessions., but it was unclear whether I was expected to facilitate any of these sessions. An email from the PAO

37 For countries without large elite law firms, the clearinghouse model is one option: a central agency assigns cases to pro bono members of the bar. In addition to matching clients with pro bono attorneys, these entities monitor the quality of the work and provide training and support to participating attorneys. Thomas Geraghty, Geoffrey Anderman, David Hamsher, Sha Hua, Nadia Majid, David Sanders \& Katherine Shaw, Access to Justice: Challenges, Models, and the Participation of Non-Lawyers in Justice Delivery, in Access to Justice in Africa, supra note 3, at 53, 80 (citing Scott L. Cummings, The Politics of Pro Bono, 52 UCLA L. Rev. 1 (2004)).

38 But see, David McQuoid-Mason, The Supply Side: The Role of Lawyers in the Provision of Legal Aid - Some Lessons from South Africa, in Access to Justice in Africa, supra note 3 at 101. Professor McQuoid-Mason writes that South Africa, as a result of British influence, has a tradition of lawyers doing some non-mandatory pro bono or "pro amico" work. Law societies in some African countries are making this compulsory for their members. Id. Under the South African model, an attorney may make a pro amico agreement with a client to work for free until a judgement is issued or a settlement reached. "Legal Beagle,"DURBS Magazine (June/July 2006), avail. at http:// durbs.kwazulunatal.com/number13/page11.shtml (last visited 6 Aug. 2010).

39 See, e.g.., American Bar Association, Model Rules of Professional Conduct, Rule 6.1, (amended 1992)(avail. at http://www.abanet.org/cpr/mrpc/rule_6_1.html) (last visited 6 Aug. 2010): “A lawyer should aspire to render at least (50) hours of pro bono publico legal services per year. In fulfilling this responsibility, the lawyer should... provide a substantial majority of the...hours without fee or expectation of fee to persons of limited means...In addition, a lawyer should voluntarily contribute financial support to organizations that provide legal services to persons of limited means."

40 See supra note 23 and infra notes 104-06 and accompanying text (describing poor physical state, materials and staffing of campuses and government buildings).

41 One long-time observer of clinical education in South Africa remarks: “...virtually all clinics rely to some degree on short-term grants. As a result, their staff must constantly engage in time-consuming fundraising, they suffer from rapid turnover as grants come and go, their case priorities are often set by the funders rather than community needs, and they have insufficient faculty to provide high quality education for their students [footnote omitted]." Peggy Maisel, Expanding and Sustaining Clinical Legal Education in Developing Countries: What We Can Learn from South Africa, 30 Fordham Int'l L.J. 374, 388 (2007). 
suggested that workshops, at least as conducted in most American "break out" 42 settings, were not a well-established mechanism in Africa; past experience told me as much. Yet, it seemed the Embassy anticipated a series of lectures from me or even some skills simulation sessions. ${ }^{43}$ In attempting to meet the expectations of sponsors and target audience, the consultant must be prepared for an alternate scenario or improvised presentations. Aware of this reality, I departed for Togo with a tentative agenda and an open mind.

\section{Le Long Voyage}

My journey had really begun before physical departure, with the research and ruminating. While it takes about a day and a half to travel to Lomé, with stopovers and time zone changes, the distance is as much cultural as it is spatial or temporal. The adjustment to the formalities, lack of amenities, slavish adherence to bureaucratic protocols, and the pace of daily life outdid the effects of jet lag.

My experience was also coloured by my rapport with my immediate hosts. They would be my guides, mentors, minders and tutors. The PAO was an ex-Peace Corps volunteer married to a musician from neighbouring Benin. She seemed to be a less conventional diplomat than her assistant, a long-time Embassy staffer and Togolese national with a daughter attending college in the United States. To be sure, they represented an elite sector of society, with slightly more mobility than the jurists I would encounter. Eventually, after my visit, both had left their jobs in Lomé, the PAO for another diplomatic post and the assistant had left for a life in America.

Our interactions would reveal a mix of American and local interests, which did not necessarily fall along predicable lines of nationality, race or diplomatic status. That is, a foreign service officer might express views at odds with the current American administration, while an African national could staunchly defend the U.S. government's position. Outside the Embassy walls, the nation's politics dominated discussion. My visit coincided with the Togolese electoral campaign, which the national television station covered extensively. The two-week campaign period had been launched he day I arrived and voters were presented with 395 party lists of candidates from at least 32 parties. ${ }^{44}$ Elections have a different significance in post-colonial Africa than in western democracies and the excitement was palpable.

Walls were plastered with partisan posters. My hotel appeared to be the headquarters for the European Union election observers, with many olive green trucks lined up in the front parking lot. I actually awoke one morning to find a photocopied letter slipped under the door of my room. It was a "Call to the Nation" from the President, urging a peaceful balloting: "Togolaises, Togolais, Mes très chers compatriotes....Vive la démocratie! Vive la paix!" ${ }^{45}$ An enlarged version of the letter was mounted conspicuously on an easel in the lobby. One would be unlikely to encounter a similar display of civic boosterism at an upscale tourist hotel, or indeed any hotel, in western countries.

42 While I acquiesce to the popular "break out" for the convening of small groups, I eschew the equally popular "report-back" for what is adequately described as a "report."

43 It is commonplace at conference workshops for clinical educators, such as those sponsored by the American Association of Law Schools or the Clinical Legal Education Association, to actually introduce a pedagogical concept through simulation or role play.

44 Une campagne blanc, rouge, jaune, Republic of Togo, 1 Oct. 2007, http://www.republicoftogo.com/central. php? $=5 \& s=83 \& d=3 \& \mathrm{i}=1058$ (last visited 2 Oct. 2009); http://www.state.gov/g/drl/rls/hrrpt/2008/af/119029. htm (last visited 9 Aug. 2010).

45 Letter from Faure Gnassingbé, President of Togo, to Togolese citizens (Oct. 2007) (on file with author). 
Anticipated with a mix of celebration and angst, this represented much more than an exercise in the right to vote freely. This tangible symbol of democracy meant the government could effect change through the political process, and opposition parties could have a chance at power.

In Togo, and the rest of post-liberation Africa, this process of alternance, or change in leadership, is itself a confirmation of belief in the rule of law. Togo has a long history under one-party rule. For over thirty years, an autocratic head of state, Son Excellence, Eyadema Gnassingbé, governed the country. Today, the dynasty continues with his son, Faure ${ }^{46}$ Like his father before him, he is addressed as His Excellency and his photo hangs on the wall of every commercial establishment. Despite this tradition of praise and obedience, the election raised expectations of democratisation in Togo. The previous general elections, in April 2005, resulted in widespread violence, condemnation by African leaders ${ }^{47}$ and a loss in foreign aid. The political elite were keen to avoid a repeat scenario. Although the electoral campaign and the results would not have a direct impact on the seminar and its outcome, it formed an important backdrop. Legal reform in general and access to justice in particular would figure as important components of a genuine democracy.

\section{$1^{\circ}$ Jour}

On the first programme day in Lomé, I held two key preparatory meetings: one with the president of the local bar association and the other with the Ambassador. ${ }^{48}$ The bar association was officially in charge of the impending workshop. Characteristically, the bar was neither sufficiently staffed nor financed to independently plan or organise this kind of event. Le Bâtonnier 'or Bar President ${ }^{49}$ is a very prestigious position in Togo, as elsewhere in francophone Africa. ${ }^{50}$

In the upcoming seminar discussions, beginning with the meeting at the bar headquarters, participants frequently invoked Article 10 of Ordonnance No. 78-35. This sole existing statute addressing subsidized legal assistance states:

Legal assistance may be granted, by decision of the jurisdiction handling the matter, to parties proving their indigence. The particulars of the assistance are governed by décret. ${ }^{51}$

Article 10, and the failure to appropriate funds and implement the law by executive decree, assumed an almost exaggerated importance. Two other documents also appeared central to the

46 Kaniye S.A. Ebek, The Succession of Faure Gnassingbé to the Togolese Presidency - an International Law Perspective, 2005 Nordiska Afrikainstitutet.

47 U.S. Dep't of State, Background Note: Togo, http://www.state.gov/g/drl/rls/hrrpt/2006/78762/htm (last visited 2 Aug. 2010).

48 David Dunn.

49 Maître Alexis Aquereburu, Bâtonnier, Ordre des Avocats du Togo.

50 On a subsequent visit to Africa, I appreciated even more the deference typically accorded the bar president. My table partners at a lavish cocktail hosted by the local bar president in Douala, Cameroon were young, but accomplished, lawyers. Although they were jovial and informal, they were not on a first name basis with the Bâtonnier. They were overly complimentary, bordering on obsequious. But, in the interest of improving my cultural competence, I must set aside my narrow American judg[e]ment about this form of interaction.

51 Art. 10, para. 2, supra note 7. Somehow this key text failed to turn up in my library research. The Constitution contains only vague and indirect references to access to justice. Constitution de la République Togolaise, arts. 11 (prohibiting favouritism or disadvantage due to economic status); 15 (banning arbitrary arrest or detention); 16 (right to counsel at time of preliminary investigation). 
debate. First the Ministry of Justice had issued a draft judicial modernisation programme ${ }^{52}$ a little more than two years earlier, noting that the legal aid fund allegedly created in 1978 never received any government appropriations. ${ }^{53}$ Second, the nation's largest bar association and law school had entered into a partnership agreement or memorandum of understanding earlier in the year. The document envisioned such activities as continuing education of the bar, theoretical and practical training of students; attorney-taught courses and curriculum planning and student externships (recevoir en stage...des étudiants). ${ }^{54}$

The modernisation programme had the potential to serve as a springboard for a fully developed legal assistance operation. There was no indication, however, that the modernisation planning document would be translated into reality. ${ }^{55}$ Curiously, prior to my arrival, no one made reference to the modernisation plan, the law school-bar association agreement or the longstanding legal assistance statute. ${ }^{56}$ The modernisation program's coordinator, Judge Hohueto, was actually present at the meeting with bar members that afternoon, but she did not appear to have a leadership role in the planning of the seminar, much less the implementation of any future legal reform.

In what constitutes a pro bono tradition in Togo, members of the Lomé bar association have occasionally visited the local prisons en masse. This effort to clear the legal backlog would occur during an annual holiday as an act of charity or concurrently with the opening of a new term of the Supreme Court, the rentrée solonelle. These journées de consultation juridique gratuites, sometimes underwritten by the American Embassy, were an ad hoc practice that had the potential for something more formalised.

Having received local perspective and background from bar president Aquereburu, I next met with Ambassador Dunn. The practice of setting up a briefing with the ambassador, particularly if he has a professional interest in a visitor's area of expertise, is not unusual in a small country. Meeting embassy expectations about a programme and its results can be challenging. The objective may be as simple as creating a space for discussion and reflection, or the objective is not articulated at all, except in the broadest of terms. ${ }^{57}$ These expectations must also be reconciled with one's own

52 Ministere de la Justice, Republique Togolaise, Programme National de Modernisation de la Justice 2005-2010 (Amended Final Draft, Aug. 2005)(on file with author).

53 ROL scholar Erik Jensen notes that "[p]ublic cynicism will grow if rules are introduced without attention to pace, sequence, local context, and of course implementation." Jensen, supra note 6 at 122. "[T]too many rules in low-capacity regimes can undermine public support and state legitimacy." Id.

54 Protocole d'Accord de Partenariat entre Le Barreau de Lomé et l'Université de Lomé. (18 Jan. 2007)(hereafter "Protocole de Partenariat")(on file with author). The stage in Anglophone Africa might be referred to as articling or pupilage, particularly if it takes place after law school graduation.

55 Jensen appropriately cautions that "[p]lanning documents, government edicts, the passing of laws, or representations made by a key political, legal, or economic actor over a meal are often taken at their face value as demonstrating elite commitment [footnote omitted]." Jensen, supra note 6 at 134. The Togolese modernisation programme, like the much-discussed Article 10 and the bar-faculty accord, was by no means a demonstration of any commitment to legal reform.

56 I say this not to chastise the hosting embassy staff or host country representatives, but as an acknowledgement that some of the obvious background materials for a visit may not be provided to the visitor.

57 On the other hand, in preparing for a subsequent two-country visit, the State Department forwarded me the embassy email messages which described the programme objectives. Although almost identical enough to be formulaic, the two emails did display a desire by embassy staff to link the programmes to larger themes important to the United States and the host country - at least on paper. (Email from Steven Lauterbach, 30 June 2010)(on file with author). 
personal or professional objectives.

To meet the Ambassador I entered a newly constructed facility. It was spacious, light and filled with potted plants and works of art. Located on the outskirts of Lomé, its main feature, like most post-9/11 U.S. embassies, was security. As is typical, the majority of employees were nationals of the host country. From airport expediter to assistant planners and programme coordinators, these are well-paid, desirable jobs. Ambassador Dunn and I spoke about the need for legal reform and what that might entail. He clearly cared about institutionalising rule of law principles and leveraging U.S. funds to do so. Acting on this interest, the Ambassador would appear at the opening of the seminar the next day along with Togolese Justice Ministry and bar association officials to speak on the issue.

\section{2e Jour}

My work began in earnest in the conference room of Ghis Palace, a modest hotel by U.S. standards, situated on the outskirts of the city. A smart hand-painted banner announcing the seminar was hung across the front of the room, reading: "Legal Aid and Strengthening of the Rule of Law in Togo." Long rectangular tables were joined together horseshoe-style. Young men arrived wearing wide neckties and pointy fashionable shoes, as did women in western and traditional dresses, together with some older men in dark suits. Ardent mid-level and junior jurists (including the daughter of the current, or perhaps former, prime minister) were seated around the horseshoe, but it was not clear whether the more senior men would remain for the work that needed to be done after the plenary. ${ }^{58}$

The plenary session ${ }^{59}$ was opened by Le Bâtonnier. In his remarks, President Aquereburu acknowledged the ineffectiveness of legal aid in Togo, in spite of measures provided in Article 10. Not as much attention was given to the concept of legal assistance itself as to its legal underpinnings or to the precise term of art, which varied from l'aide juridique to l'assistance judiciare to l'aide juridictionelle ${ }^{60}$ The Bâtonnier expressed hope that the seminar work would establish the necessary support for implementing a legal aid programme for the poor.

In another set of opening remarks, Ambassador Dunn noted how the United States, along with bilateral and multilateral partners, had participated in the process of modernisation of Togo's courts. He told those assembled that his Government - that would be mine - sought to establish a judicial system that protects and respects individual and group liberties, as well as fundamental rights $\cdot 61$

58 More than one participant later expressed regret on their evaluation forms that more senior attorneys did not attend the seminar. Another thought the workshop sessions were very useful. Fiches d'Evaluation (on file with author). Many of the younger lawyers later stated their unhappiness with the location of the seminar. Id. See infra text accompanying notes 130-31. Although lunch and a stipend were provided, the cost of transportation outside the city centre was significant.

59 A young conscientious law graduate, Darius Atsoo, prepared an almost contemporaneous summary of proceedings on his laptop. See, Rapport Général du Seminaire: Aide Juridictionelle et Consolidation de l'Etat de Droit Au Togo (2-4 Oct. 2007) (hereafter Rapport Général du Seminaire) (on file with author). I afterwards received periodic requests from Me. Atsoo for me to friend him on Facebook - even before I had joined myself.

60 Me. Amazohoun, a young lawyer and one-man human rights NGO, had his Dalloz Dictionary handy to look up cross-references for the various terms, which seem to be interchangeable.

61 Rapport Général du Seminaire, supra note 59 at 2. 
Following Dunn's remarks, the cabinet attaché from the Justice Ministry ${ }^{62}$ described the seminar as part of a vast and ambitious programme of justice modernisation and reiterated that the essential subject was legal aid. He thanked President Gnassingbé for "nourish[ing] his people with the hope of a promising future through the legal system" and emphasised that justice is "at the heart of the new societal contract" to which Togo had subscribed. Despite this ceremonial endorsement by the Justice Ministry, the next speaker, Judge Agbetomey of the Supreme Court, was among many to note that the Executive had never adopted an implementing degree for Article $10 .{ }^{63}$ The usual round of comments and questions followed. Hands were raised and the moderator called on three people at a time. Each person began by thanking the speaker for valuable remarks and then delivered a lengthy comment or posed a question.

In response to Agbetomey's address, seminar participants suggested that consumer-friendly orientation and assistance booths be stationed in strategic locations, possibly in courthouse lobbies. They also agreed to implement specific recommendations at the end of the seminar, which would serve as the foundation of a décret implementing Article 10. This decree would address such matters as the definition of indigence, legal aid eligibility, amount of legal aid, qualifications for assistance and the procedure for requesting aid.64

Professor Kpodar of the law faculty was among the few speakers to offer concrete suggestions. Legal aid, he declared, is at the heart of human rights protection but could not be effective if citizens' access to justice in their own country is not facilitated by the State through adequate human and financial resources. He urged that assistance be made available to the most impoverished in order to avoid the "ill-fated effects of private justice" that result in violence.

Kpodar suggested that the concept of legal aid to the indigent be sufficiently publicized ${ }^{65}$ and integrated into general university programmes, and law school programmes in particular. He called for the creation of a Centre for Law and Reflection, under the supervision of lawyers, judges and university faculty. The centre would be staffed by students preparing for their $\mathrm{CAPA}^{66}$ or for the national judiciary college, the Ecole Nationale de la Magistrature. ${ }^{67}$

It is not clear whether the centre Kpodar proposed would be more inclined toward service than scholarship. Nonetheless, the ability of law school faculty to run such a legal clinic themselves is

62 Id. at 2-3 (representing the Attorney General and the Ministry of Justice).

63 Remarks of Judge Pius Kokouvi Agbetomey, Togo Supreme Court. Id. at 3.

64 Id.

65 Professor Frank Bloch argues that before legal aid is made readily available, the people must first be made aware of their rights. Bloch, supra note 31 at 118 . The so-called "street law" courses offered in many U.S. law schools are a good model for supporting law students who in turn provide lay outreach and community education courses to members of marginalized communities. Wortham, supra note 6 at 660 . See also, Philip F. Iya, Fighting Africa's Poverty and Ignorance Through Clinical Legal Education: Shared Experiences with New Initiatives for the 21st Century, Int'l J. Clin. Legal Ed. 13, 17-19 (Nov. 2000)(law school involvement in community outreach programmes).

66 The CAPA (Certificat d'Aptitude à la Profession d'Avocat) is the postgraduate legal qualification needed to practise law.

67 Remarks of Prof. Adama Ferdinand Kpodar, Assistant Dean, Faculty of Law, Univ. of Lomé. Rapport Général $d u$ Seminaire, supra note 59 at 3-4. 
highly questionable, given their theoretical training and orientation. ${ }^{68}$ In the end, the support of senior faculty would be essential ${ }^{69}$ to the survival of any curriculum change made to accommodate the clinic, particularly those changes that might involve a reallocation of teaching resources and other funds or the awarding of academic credit. ${ }^{70}$

In remarks entitled "The Necessity of Teaching Legal Aid to Students," Maître Attoh-Mensah echoed Professor Kpodar's emphasis of the need for State financial aid. He defined legal aid as a subsidy granted by the State to allow its poorer citizens to exercise their legal rights in legal matters (mâtière gracieuse ou contentieuse). ${ }^{71} \mathrm{He}$ recommended that judges, lawyers and other legal professionals familiarise themselves with the free legal aid concept at an early stage in their training so they could integrate it in their professional lives. ${ }^{72}$ He argued that the Bar's recognition of legal aid as a necessity for improving access to justice was an important step in the struggle to provide assistance to the underserved. To capitalise on this momentum, Attoh-Mensah asserted that the political and legal authorities should be encouraged to implement an adequate means to provide effective legal aid.

Attoh-Mensah also affirmed the importance of teaching about legal assistance to CAPA students and endorsed Kpodar's proposal of a legal aid outreach campaign amongst law students. In addition, he said students should be allowed to participate in the preparation of case files for

68 For example, Professor Peggy Maisel posits that the "lack of capacity stems initially from the fact that virtually none of [the] South African law professors had the opportunity to participate in clinics themselves while in law school. Therefore, they were forced both to establish law clinics and to create a related curriculum without having had any personal experience of what a clinic looked like or how it operated [footnote omitted]." See Maisel, supra note 41 at 409-10. This point was driven home when some colleagues and I formed the Projet Clinique Juridique Berkeley-Goma and attempted to link a private university law school in the eastern Democratic Republic of the Congo with legal assistance to survivors of gender-based violence. While expressing interest in a practical and service-orientated delivery model, the faculty's proposal was grounded more in research, data collection and publication than the practise of law and assistance to traumatised clients.

69 Wortham, supra note 6 at 668. On more than one programme visit, my embassy interlocutors have cautioned that the senior faculty (or attorneys) may express interest in a proposal but will try to delegate follow-through to less influential junior faculty (members of the bar). This phenomenon is not unique to African universities and professional associations. Professor Wortham observes that while senior faculty may be dubious about new pedagogy, such as the clinical model, students will almost always happily embrace the change. Id. at 681 .

70 Professors Geraghty and Quensah explain that African law schools, like their American counterparts before them, may need to hire recent graduates to teach in clinical programmes. Besides the know-how and enthusiasm they will bring to the job, these junior faculty members will be less expensive. Geraghty \& Quensah, supra note 14 at 103 . While the majority of existing African law school-affiliated clinics do not award academic credit, id. at 101 , this is not necessarily a deterrent to student enrolment. For an account of the challenges in implementing clinical curriculum in a relatively new African university, see T.O. Ojienda \& M. Odour, Reflections on the Implementation of Clinical Legal Education in Moi University, Kenya Int'l J. Clin. Legal Ed. 49 (June 2002). See also, Iya, supra note 65 at 16-24 (genesis and application of clinical legal education in Africa and experience in different countries).

71 Remarks of Sylvain Attoh-Mensah, Member of the Bar and RADAR (Réseau contre les arrestations et les détentions arbitraires). Rapport Général du Seminaire, supra note 59 at 4-5.

72 Lawyers may graduate from the faculty of law without any training in human rights laws and practices or the "knowledge and requisite skills in contemporary and innovative approaches to rendering legal aid." Nchunu Justice Sama, Providing Legal Aid in Criminal Justice in Cameroon: the Role of Lawyers in Access to Justice in Africa, supra note 3 at 161-162. Inculcating students with the concept that social justice work is a part of professional obligation is an important objective of transformative legal education. See, Bloch, supra note 31 at 116, 126. 
hearings and to organise pro bono legal intake days in collaboration with the bar association. ${ }^{73}$

Lastly, he proposed the establishment of a legal assistance fund administered by a committee of judges, lawyers and others. The funding source could be the appellate court fines and interest on fees deposited by court clerks in bank accounts. Attoh-Mensah's remarks elicited favourable comments. Some participants noted that an effective aid programme would permit eradication of the unseemly practice by which lawyers "sell their wares" (démarchage) in the the Lomé courthouse corridors. ${ }^{74}$

I spoke next, offering a way to put these ideas into action by presenting American legal aid options and those that have prevailed in certain African countries. ${ }^{75}$ It remains surprising that a white American lawyer from a common law regime has something to say to French-speaking, ${ }^{76}$ black African jurists working in a Germano-Roman civil law system. Yet, these differences failed to raise large obstacles to communication despite their divisive potential. To the contrary, I felt a bond that was both professional and personal. ${ }^{77}$

In the same vein, one might ask why a former French colony would look to the United States for technical assistance? Our language, legal and educational systems, and culture are so distinct from what these nations inherited from France, and continue to rely on in government, schooling, commerce and public discourse. ${ }^{78}$ Notwithstanding their linguistic and legal legacy, and mostly positive diplomatic and economic relations with the French, the Togolese may experience a lingering distrust or even rejection associated with their ex-coloniser. ${ }^{79}$ The U.S. system, putting aside our own history of hegemony, does provide an instructive model for examining

73 Rapport Général du Seminaire, supra note 59 at 4-5. The lack of hands-on training for African law school students was made vividly clear in the handling of Malawi capital crimes cases some years ago. Of 91 cases, it was reported that "out of the seven lawyers in the [defence counsel] department, three had just been recruited from university and their first trials were capital cases (footnote omitted)." Stapleton, supra note 3 at 15 . The inexperience was compounded by the fact that most of these lawyers had just met their client for the first time "minutes before the trial began." Id. Although a similar critique can be made about neophyte or overworked American criminal defence counsel for the indigent, the consequences are obviously different for a misdemeanor, or even felony, than for a crime that could result in the death penalty.

74 Id. The public's ignorance of their rights, along with the perception of lawyers "as some sort of money-grabbers, rather than as professionals disposed to provide legal aid...," has also been a barrier to accessing legal services in neighbouring countries. Sama, supra note 72 at 160.

75 Rapport Général du Seminaire, supra note 59 at 5-7.

76 Language is itself a wonderful vehicle for bonding. If the American consultant can bridge the language gap-one of my strongest assets - she or he may well be a winner in public diplomacy. While my communications outside of embassy staff are always in French, I try to sprinkle in a few greetings or other phrases in the so-called national (ethnic) languages that audience members have in common - be it Ewe, the Togolese native tongue, Wolof or Chadian Arabic.

77 But see, Haider Ala Hamoudi, Toward a Rule of Law Society in Iraq: Introducing Clinical Legal Education into Iraqi Law Schools, 23 Berkeley J. Int'l L. 112, 120, n. 46 (2005) (fact that U.S. consultants were ethnically Iraqi was critical to gaining trust of their hosts).

78 Professor Dauphinais notes that the end of colonialism actually allowed for the advent of a legal culture and innovative educational methods - such as those established in the United States - that offer something other than those "received" from the former colonial power and ill-suited to contemporary social needs. Dauphinais, supra note 10 at 67-69, 87-88.

79 It remains to be seen whether France can "reinforce [its] place," in the words of the Foreign Minister, in language, ideas, art and science with the recent creation of the Institut Français. The agency is to oversee 143 cultural centres throughout the world. Bernard Kouchner, "La culture française a les moyens de rayonner à l'étranger," Le Figaro, p. 21 (22 July 2010). 
contemporary judicial and legal educational innovations - beyond the general caché associated with Made in America. ${ }^{80}$

There was a long period of incubation before the American institutions of democratic governance and due process protections took shape, I explained to the audience. The Supreme Court required 170 years to clearly define the contours of the Sixth Amendment to the U.S. Constitution - a fundamental provision of the Bill of Rights establishing the principle of legal assistance to those accused of committing a crime. ${ }^{81}$ Extending the right to counsel for the indigent can be a long process in the making for a relatively young government and legal regime. In Togo, the practices and funding would take time to catch up with the legal texts. This slow development of a right to representation contrasts with the civil law system of stipulated rights inherited from the French colonial empire.

I went on to describe a second unique method of the American legal system that could be instructive in Togo's struggle to provide services to the indigent: the development of clinical programs. Through these programmes, law schools have set up clinics permitting students to work under the supervision of lawyers, or skilled teachers, and hold them accountable to indigent clients. ${ }^{82}$ Indeed, clinical education has developed elsewhere in Africa, in Anglophone countries ${ }^{83}$ and in legal regimes with no longstanding clinical or practice-orientated tradition. ${ }^{84}$ Although the

80 In addition to clinical legal education and pro bono representation, the themes of an independent judiciary, mediation and alternative dispute resolution are also popular and have made up the core of my other African programme visits.

81 Gideon v. Wainwright, 372 U.S. 335 (1963).

82 A trend that began in the United States and moved to post-Soviet Europe is now enshrined in European Union higher education curriculum policy. See generally, Lusine Hovhannisian, Clinical Legal Education and the Bologna Process 12-17 (Public Interest Law Institute, 2006), avail. at http:/old.pilnet.org/index. php?option $=$ com_content $\&$ view $=$ article $\& i d 456$ :pili-papers-no2 \& catid=122:featured (last visited 21 Nov. 2011). The so-called Bologna Process is an attempt to make EU higher education systems more compatible, competitive and quality enhanced. Id. at 16 .

83 In conversations on a subsequent visit to Cameroon, my interlocutors suggested that the dominant Frenchspeaking civil law regions of the country might be more receptive to the concept of pro bono, and perhaps clinical education, if they saw successful models in English-speaking western Cameroon, with its common law tradition - or perhaps even neighbouring Nigeria, which now boasts six law faculty legal aid clinics. See, Sama, supra note 72 at 156, 158 (noting common law practice of assigning defence counsel in capital cases and early $21^{\text {st }}$ century bar association experience with public legal aid centres, in partnership with the British Council). See also, Network of University Legal Aid Institutions, Open Society Justice Initiative \& Open Society Institute, Clinical Legal Education Curriculum for Nigerian Universities' Law Faculties/Clinics (Oct. 2006).

84 This is not just about North meets South, i.e. First World meets Third World. There are a number of countries without a vigorous tradition of public interest lawyering, much less law school preparation for this kind of practice or practical training. See, e.g., Peter A. Joy, Shigeo Miyagawa, Takao Suami \& Charles D. Weisselberg, Building Clinical Legal Education Programs in a Country Without a Tradition of Graduate Professional Legal Education: Japan Educational Reform as a Case Study, 13 Clin. L. Rev. 417 (2006). Professor Grady Jessup suggests that a "development law clinic" - not to be confused with the discredited "law and development" movement - is a worthwhile model for those in developing nations, as it is concerned with nation building or national development." Grady Jessup, Symbiotic Relations: Clinical Methodology - Fostering New Paradigms in African Legal Education, 8 Clin. L. Rev. 377, 400 (2002). Its "design and curricular offerings would take into account the conditions of the country and train law students as future leaders and lawyers to help address those conditions [footnote omitted]." Id. 
clinical model, as we have come to praise it, is not intrinsic to common law, ${ }^{85}$ the development of law school clinics to provide service appears to be a creature of the Anglo-American system. In contrast, the Western European civil law countries - and France in particular ${ }^{86}$ - have historically failed to embrace clinical education or formation pratique. ${ }^{87}$

A third easily translatable method for providing service employed in the U.S. legal system is the notion of mandatory pro bono hours for every practising attorney. The American Bar Association has "set the bar" by placing responsibility on each attorney to aspire to contribute a certain number of uncompensated hours to the defence of indigent clients and worthy cases or causes. ${ }^{88}$ In Africa, a system of pro bono work may be emerging, in which lawyers and paralegals provide free representation to indigent criminal defendants, independent of any state aid. ${ }^{89}$ Paralegals have

85 For an overview of models for clinical education outside the United States, with an emphasis on rationale and the importance of diverse, organic and country-specific programmes, see generally, Wortham, supra note 6 and Bloch, supra note 31. Professor Bloch warns against adopting a "clinical imperialism" approach in designing overseas curriculum and programme. Id. at 132. This advice could also be heeded on one's home turf. See, Suzanne M. Rabé and Stephen A. Rosenbaum, A "Sending Down" Sabbatical: The Benefits of Lawyering in the Legal Services Trenches, 60 J. Legal Ed. 296, 297, n. 2 (2010) (commenting on divisions amongst law faculty engaged in the clinical or experiential education enterprise). See also, Richard J. Wilson, Ten Practical Steps to Organization and Operation of a Law School Clinic (Feb. 2004) (unpublished paper on file with author) (mechanics of creating a clinic) and Ojienda \& M. Odour, supra note 70 at 53-59 (suggestions on implementing clinical programme at African university). Kenyan Researchers Ojienda and Odour write that clinical legal education "has been defined simply as learning law by doing law... a method of instruction in which students engage in varying degrees in the actual practice of the law." Id. at 49 (citation omitted).

86 In a telling remark, a colleague on the Université d'Artois law faculty replied to one of my emails with: "Qu'est-ce que tu entends par' clinique juridique??" ("What do you mean by 'legal clinic'?")(Email from Arnaud de Raulin, 15 Aug. 2007)(on file with author). Professor Rick Wilson writes of one dual-degree French student who quipped: "After studying in France, I have no idea what the practice of law in France must be like." Wilson, supra note 11 at 832. For an explanation of the resistance of civil law countries to clinical education, see Norbert Olszak, La Professionalisation des Etudes de Droit: Pour le Developpement d'un Enseignement Clinique, 18/7203 Recueil Dalloz 1172 (5 May 2005)(noting benefits of the venerable medical school training model and France's lagging approach to clinical education for law students).

87 Reforms in European legal education call for more emphasis on practical experience. See, Hovhannisian, supra note 82 at 14 (EU reform spurred by "rapidly changing legal environment," growing number of students and, in post-Soviet Europe, by governments transitioning to democracies). Notwithstanding the relatively late and tentative experimentation with clinical education in many civil law countries, there is nothing inherently incompatible between this methodology and the civil law system. But see, Pamela N. Phan, Clinical Legal Education in China: In Pursuit of a Culture of Law and a Mission of Social Justice, 8 Yale Hum. Rts. \& Dev. L.J. 117, 140 (2005)(noting importance of recognising system differences).

88 American Bar Association, Model Rules of Professional Conduct, Rule 6.1, supra note 39. Although the tradition in the United States is longstanding and increasingly formalized, it was not until October 2009 that the first national pro bono week was inaugurated.

89 See, e.g., African Commission on Human and Peoples' Rights (ACHPR) Resolution on the Right to a Fair Trial and Legal Assistance in Africa (1999) and Dakar Declaration and Recommendations (hereafter, 1999 ACHPR Resolution/Legal Assistance and Dakar Declaration), supra note 91 at 169, 175 (states parties should "[i]n collaboration with Bar Associations and NGOs, enable innovative and additional legal assistance programs to be established including allowing paralegals to provide legal assistance to indigent suspects at the pretrial stage and pro-bono representation for accused in criminal proceedings"). See also David McQuoid-Mason, A Series of Pointers Clarifying the Role of Paralegals, in Access to Justice in Africa, supra note 3 at 291-295. 
made a significant contribution to the legal assistance efforts in some nations 90

I concluded my remarks by describing some of the independent efforts within Africa to incorporate the idea of pro bono service into the practice of law. Various declarations and other accords adopted by the African Commission on Human and Peoples' Rights in the last decade or earlier call on the courts, the bar and law faculties to take on a greater role in assuring the judicial systems are accessible to their fellow citizens, particularly long-term detainees. ${ }^{91}$ Although ratification of these texts does not by itself guarantee effective implementation, ${ }^{92}$ the principles enunciated in them should nonetheless inform any African legal aid scheme. ${ }^{93}$

Curiously, most seminar participants at Ghis Palace seemed to be unfamiliar with the declarations and action plans adopted by a series of African congresses of jurists, all of which have provisions requiring their promulgation and publication for lawyers, law students and the population at-large. Again, the existence of the texts does not ensure that they are transmitted, even to those studying, teaching or practising law. ${ }^{94}$ This lack of familiarity also applied to knowledge about legal aid laws on the books in neighbouring countries, some dating back to the early years of independence. ${ }^{95}$

Despite the relevance of outside models, I kept in mind the reality that in adapting a legal aid model, each country must take into account its own laws, traditions, habits and customs. ${ }^{96}$ "The transplantation of laws and legal institutions is not always wrong, but formalistic transplantation should come with a caveat emptor. . . ."97 Intermediary authorities can be more effective when

90 See, e.g., Clifford Msiska, Rhoda Igweta \& Edouard Gogan, The Paralegal Advisory Service: A Role for Paralegals in the Criminal Justice System, in ACCESS TO JUSTICE IN AFRICA AND BEYOND, supra note 3 at 145 and Geraghty et al., supra note 37 at 65-71 (discussing virtues of paralegal model). See also Henry Phoya, The View From Government, in id. at 31-32 (court backlogs and insufficient numbers of lawyers, as well as traditional reliance on informal justice, favour Malawi's Paralegal Advisory Service) and Vivek Maru, Timap for Justice: A Paralegal Approach to Justice Services in Sierra Leone, in id. at139 (variety of advocacy tasks provided by Timap ("Stand Up Together") paralegals, based on South African model, in nation where there is distrust of corrupt formal justice system and rural population has no access to lawyers).

91 See, e.g., Lilongwe Plan of Action, supra note 32, at 48-49. See also, UN Basic Principles on the Role of Lawyers (1990), reprinted in Access to Justice in Africa, supra note 3 at 268-269; and 1999 ACHPR Resolution/Legal Assistance and Dakar Declaration reprinted in id. at 169, 177 ("Bar Associations should...[e]stablish programs for pro-bono representation of accused in criminal proceedings...").

92 Sama, supra note 72 at 161.

93 See generally, ACHPR Resolution on the Right to Recourse and Fair Trial [sic] (1992) in Access to Justice in Africa, supra note 3 at 167-68 (right of detainees to prompt judicial review, trial within reasonable time, legal aid for the needy. See also ACHPR Resolution/ Legal Assistance and Dakar Declaration, id. at 169, 173 ("It is the duty of governments to provide legal assistance to indigent persons in order to make the right to a fair trial more effective.").

94 See, Geraghty \& Quensah, supra note 14 at 97, 99 (outdated texts, inaccessible legal information and technology, poorly stocked libraries) and Dauphinais, supra note 10 at 104-05 ("sophisticated-looking statutes and regulations" belies actual knowledge and familiarity due to unavailability of legal texts).

95 See, e.g., Loi No. 61-103/AN-RM du Mali (18 Aug. 1960)(statute setting out terms for legal assistance in civil and criminal matters) and Arrêté du Sénégal (31 Jan. 2006) (establishing commission to administer legal aid funds). Again, enacting legislation is only the first step. Professor Bloch recently observed that "the overall state of access to justice in Africa remains 'incomplete' due largely to the lack of government-sponsored legal aid schemes." Bloch, supra note 31 at 118 n. 21 (citing First All-African Colloquium on Clinical Legal Education (June 2003), avail. at http://www.justiceinitiative.org/acivities/led/cle/durban2003/Durban_report.pdf).

96 Sarah Cliffe \& Nick Manning, Practical Approaches to Building State Institutions, in Charles T. Call, supra note 6 at 169 .

97 Jensen, supra note 6 at 136. 
dealing with laws that are "broadly compatible with the pre-existing legal order" 98 and governments are more likely to allocate resources to enforcing and developing the law and legal institutions when adapted to local needs. Furthermore, without such integration of the pre-existing legal structure, the challenge of providing access to justice would prove to be much more formidable.

Mediation and other means of informal dispute resolution are some of the compatible models I highlighted for the seminar audience. ${ }^{99}$ While one can hope to improve access to courts and enchance the court personnel and infrastructure, a far more affordable and realiseable short-term goal may be to sensitise village or neighbourhood chefs, councils of elders and family law judges, already engaged in traditional African conflict resolution, about contemporary human rights and other legal norms. ${ }^{100}$ The focus on encouraging good decisions at the local level also helps to strengthen new laws. ${ }^{101}$

Lastly, having proposed several models for guidance and discussed their applicability, I urged the creation of a law school-associated clinic in Togo, which could really benefit from a theory-practice collaboration resulting from the recent partnership agreement between the local bar association and the University of Lomé. ${ }^{102}$ In short, Togo presented a rare opportunity to establish a clinic in

98 Id. (based on extensive regressions; footnotes omitted). The observation is not peculiar to developing countries. "Historically, the legal profession has resisted change and is generally slow to adapt to modifications to a system in which lawyers feel knowledgeable and adept....lawyers will be more accepting of change if they feel that they are involved in the process, rather than having change forced upon them.(citations omitted)." Michael King, Arie Freiberg, Becky Batagol \& Ross Hyams, Non-Adversarial Justice 230 (2009).

99 The movement to use alternative forms and forums for resolving legal disputes is one of the most dramatic changes in the practice of law, beginning in the latter part of the twentieth century and continuing. According to a group of common law scholars, "The emergence of a wide range of non-adversarial processes requires a re-appraisal of the conventional view of the lawyering role." Id. at 230. Embracing non-adversarial methods also requires a change in legal education; clinical education already incorporates a good dose of non-adversarial justice methodology. Id. at 240-43, 248-50.

100 See, Stephen A. Rosenbaum, Le règlement non-juridictionnel comme alternative aux situations de crise in Situations d'urgence et de droits fondamentaux (2006). This chapter, outlining the benefits of the Senegalese-inspired M.A.R.C. (Méthodes Alternatives du Règlement des Conflits), was drawn from remarks I made at the EtatsGénéraux de la Justice, 16-19 June 2003, N’Djaména, Chad.

101 Open Society Institute, Ensuring Justice for Vulnerable Communities in Kenya (2004) 26 (comments of former Kenyan national human rights commissioner). The so-called "customary law" offers its own rules and norms in a parallel system of justice. Sama, supra note 72 at 153 . The Togolese Constitution recognises the traditional chefs as the guardians of local traditions and customs (us et coutumes). Constitution de la Répblique Togolaise, art. 143. There is a school of thought favouring "deformalizing and deprofessionalizing" dispute settlement in developing countries as a means of assuring poor people's access to lawyers, rather than "seeking to put more lawyers for the poor into the existing formal court structure." See, Wortham, supra note 6 at 636 (summarising Professors David Trubek and Marc Galanter's critique of the Law and Development Movement). This conclusion, Professor Wortham adds, anticipates the arguement in the United States about the value of ADR. Id.

102 Protocole de Partenariat, supra note 34. But see, Dauphinais, supra note 10 at 62 (customary laws may be inadequate for and detrimental to development, and multiplicity of legal systems may constitute barrier to national unity). 


\section{French-speaking Africa. ${ }^{103}$}

Despite the adaptability of the nascent legal infrastructure, setting up any legal clinic would require mastery of some less theoretical dilemmas. As noted, lack of funding and staffing is a huge obstacle for legal clinics in developing countries. The most dilapidated U.S. inner city school is a palace next to some African university campuses. It is not simply that the paint is peeling, windows are cracked, the paths are unpaved and landscaping is untended. ${ }^{104}$ Office space is limited and lacking in the usual fixtures and furnishings, classrooms are scarce and libraries are comprised of a few bookshelves and a single computer terminal. ${ }^{105}$ The commons, cafeteria, secretarial pools ${ }^{106}$ and student meeting rooms are all but non-existent. By comparison, contemporary U.S. law school clinics filled with carrels, computers and phones - and even the vintage storefront legal aid offices - are very well appointed. Before locating a physical space for a future clinique juridique, it would be necessary to secure the personnel and institutional commitment.

\section{3e Jour}

In the last of the formal seminar presentations, Judge Hohoueto, the Modernisation Programme coordinator, spoke, appropriately enough, on the theme of "Legal Aid and the Modernisation of Justice in Togo." 107 She described the six objectives of the national program, which included improving accessibility to the legal system. Hohoueto stated that widespread illiteracy and ignorance of law were factors that impeded the effectiveness of measures, such as the indigence

103 After my trip to Togo I learned that Rwanda's Université Nationale Rwandaise and Université Libre de Kigali have each established a clinique juridique in recent years. The former has a walk-in clinic affiliated with the law faculty in Butaré. See, http://www.law.nur.ac.rw/spip.php?article17 and http://www.tufts.edu/talloiresnetwork/?pid=180 (last visited 19 Dec. 2010). Its rural-based clients walk miles for a consultation. Kigali offers a one-credit legal aid clinic for third year students. See, http://www.ulk-kigali.net/index.php?page=programme---department-oflaw. (last visited 9 Aug. 2010). However, Rwanda's official language is now English, since the Government transformed its entire education system from French to English in 2008. What was ostensibly a move by the former Belgian colony to join the predominantly Anglophone East African Community and the Commonwealth was also "a means of rejecting Francophone influence and its association with the Hutu regime responsible for the genocide." Chris McGreal, "Rwanda to switch from French to English in Schools," The Guardian (14 Oct. 2008). A French-speaking clinic has operated in Morocco for a few years, with support from the American Bar Association Rule of Law Initiative. See infra, note 115.

104 Of course, how can the grounds be better kept for universities and government ministries if the presidential quarters are not "up to code?" An investigative reporter who recently returned from Guinea describes the presidential compound in terms romantic but despairing: "a series of flat-roofed three-story buildings made out of breeze blocks and painted light green, beige, and apricot...," reminding him of low-income housing projects in Florida. Jon Lee Anderson, "Letter From Guinea: Downfall," New Yorker 26, 29 (12 Apr. 2010).

105 Professors Geraghty and Quensah declare that law school libraries “are in a sad state.” Geraghty \& Quensah, supra note 14 at 99 . Professor Dauphinais writes of the acute paper shortage and out-of-print textbooks in Tanzania and Uganda, "so that even local materials cannot be mimeographed for distribution to students... students compete for a tattered copy [of a casebook or text] in the library... [and] rely heavily on notes taken during lectures." Dauphinais, supra note 10 at 72 . Upon his return from a short-term stint in Sierra Leone, San Francisco Attorney Elan Emanuel noted the same infrastructure deficiencies in government offices, where electrical power shortages were a regular occurrence and one photocopier was shared by an entire agency. (Conversation of 26 Apr. 2010).

106 The shortcomings are not limited to facilities. Staff productivity may also be lacking. I am reminded of the public sector librarians in Conakry, Guinea who seemed to be on a day-long coffee break. Apparently, things have changed little, several years - and one new Government - later. A recent visitor to the Minister of Justice writes how he was escorted "past [the] receptionist, who was watching cartoons on TV with several other women." Anderson, supra note 104 at 30.

107 Remarks of Judge Evelyne Afiwa Kindena Hohoueto. Rapport Général du Seminaire, supra note 59 at 7-8. 
provisions of the Code of Civil Procedure. ${ }^{108}$ Following Judge Hohoueto's remarks, some of the assembled jurists raised questions about the issue of court fees and costs and their impact on access to justice. The modernisaton programme called for 100 million CFA francs to be set aside in special funds, expended over five years on an experimental basis to finance legal aid for the poor.

Not only do lawyers and notaries charge fees, but the marshals and bailiffs also require payment before service of summonses or subpoenas, or the seizure of goods. ${ }^{109}$ As there seemed to be no provision in Togolese law for fee waivers, judicial process was simply unavailable for numerous would-be litigants. ${ }^{110}$

After the discussion, participants divided into two working groups: The first group's theme, predictably, was: "Reflection and Proposal of a Legal Text on the Utility of Legal Aid in Togo." The second theme was: "Reflection and Writing a Programme for Teaching Legal Aid to CAPAlevel Students."

I sat in on the second working group, where some of the seminar's formal plenary session protocols had carried over. In an American setting, a scribe or reporter might volunteer to do duty at this juncture. In this working group, however, a chair was chosen more-or-less by acclamation; he then received comments from the others in an orderly fashion. None of the academics - if any remained at the symposium - participated in this group, but there were veteran attorneys and those who had recently been students themselves. It also appeared that any recommendations made at this gathering about a changed curriculum or establishment of a legal clinic would be subject later to a formidable and centralized decision-making process. At a minimum, a change in law school policy or practice would need approval by University authorities or even the Ministries of Education and Justice. ${ }^{111}$

The working group discussed the addition of new law courses: Legal Aid, Social Justice, Clinical Techniques, Legal Practicum. There was also talk about training paraprofessionals, and references

108 Sections 405, $406 \&$ 407. A lawyer activist from neighbouring Cameroon agrees that illiteracy and rural isolation contribute to the lack of awareness of legal aid schemes and fundamental rights. Sama, supra note 72 at 160.

109 In the Democratic Republic of Congo, for example, police officers may ask crime victims for "fees" before an investigation or arrest. International Bar Ass'n \& Int'l Legal Assistance Consortium, Rebuilding Courts and Trust: An Assessment of the Needs of the Justice System in the Democratic Republic of Congo 21(2009) (hereafter Rebuilding Courts and Trust), avail. at http://www.ibanet.org/Article/Detail.aspx?ArticleUid=6C2BE523-F512-48C1-B09CFC9A8B1D0AAB.

110 Even in countries that allegedly offer fee waivers, it may still be difficult to actually obtain one. For instance, in the Democratic Republic of Congo, a would-be legal aid recipient must first obtain a certificate of indigence. Local authorities may charge from $\$ 15$ to $\$ 30$ issue one. Rebuilding Courts and Trust, supra note 109 at 21 . Under Cameroonian law, attorney services must be remunerated, which "seems to erode the very essence of legal aid, as it implies that...lawyers are only available to those who can pay." Sama, supra note 72 at 154 (citing Law to Organise Practice at the Bar, No. 90-59, § 1 (19 Dec.1990)).

111 According to one analysis, it has been the private law schools - with their younger generation of faculty and competition for students - who have been quick to embrace innovative curriculum, such as clinical education. Hovhannisian, supra note 82 at 14-15. In the francophone African academic world, this observation is borne out by the receptiveness of both the Universite Libre de Kigali (Rwanda), see supra note 103, and the Université Libre des Pays des Grands Lacs (DRC), which has recently indicated an interest in starting a law school clinic, in partnership with an NGO, to serve survivors of gender-based violence in rural Eastern Congo. 
to clinical education in South Africa. ${ }^{112}$ Externships, as part of the law school curriculum, could offer future lawyers the opportunity to work directly in law firms, NGOs and public law offices. For example, students would work under the supervision of an attorney for a specified time, for the purpose of acquiring professional experience, absorbing values inherent to the profession and mastering the professional code of ethics. ${ }^{113}$

In examining possible curriculum changes, the group focused on instituting practical or skillsbased clinical education, inculcating the spirit of volunteerism and social justice, permitting students to acquire legal knowledge before becoming practitoners. As already noted, there are now legal clinics throughout Africa. These clinics sometimes specialize in a particular field of law or clientèle. ${ }^{114}$ But, with few exceptions, these clinics are all situated in Anglophone countries with a common law tradition. ${ }^{115}$

Nonetheless, the obstacles to developing law school clinics in Africa have more to do with traditional legal educational models than the country's particular inherited legal scheme. This problem begins with the type of instructors available. For the most part, professors are recruited directly from the Academy, with no law practice experience or training. Classes are almost exclusively about theory, delivered lecture style in a large hall, with minimal to no student

112 For lessons gleaned from the South African experience, see generally Maisel, supra note 41. See also, David McQuoid-Mason, The Supply Side: The Role of Lawyers in the Provision of Legal Aid - Some Lessons from South Africa, in Access to Justice in Africa, supra note 3 at 112: (law clinics provide free legal services to the needy in the lower and high courts in both criminal and civil matters in South Africa; law students may not represent clients in court but may work on other aspects of cases.

113 The literature on externships is too voluminous to cite here. With regard to programmes for large student bodies, see, e.g., Mary Jo.Eyster, Designing and Teaching the Large Externship Clinic, 5 Clin. L. Rev. 347 (1999) and James H. Backman, Practical Examples for Establishing an Externship Program available to Every Student, 14 Clin. L. Rev. 1 (2007). For an extensive annotated bibliography on externships, visit http://www.cua.eduen Practical Steps/lexternweb/index/htm.

114 See Geraghty et al., supra note 37 at 75 (noting that many nations have established, or are currently establishing, legal aid clinics associated with law schools). Clinics exist in Sierra Leone, Ghana, Nigeria, Kenya, Uganda, Tanzania, Zimbabwe, Botswana, Malawi, South Africa and Lesotho, although not all are affiliated with law schools. Geraghty \& Quansah, supra note 14 at 100. Clinics have also been put in place in Rwanda, Morocco, Egypt and Ethiopia, where the legal systems are not derived from English common law. A new environmental law clinic opens its doors in February 2012 at the Helwan University Faculty of Law, just outside Cairo.

115 In 2005, a human rights legal aid clinic was established at the Mohammedia, Morocco law faculty at the University of Hassan II with support from the American Bar Association African Initiative and the U.S. State Department. Moroccan law is based on French civil law and French is still the primary language of university instruction. The clinic, the first of its kind in North Africa, is now under law faculty management. https:/www.abanet.org/rol/news/news-morocco-curriculum-addition.html (last visited 26 June 2010). See, Practical Manual for Activities of the Centre de Conseil et d'Assistance Juridique pour les Droits Humains (Mar. 2006)(on file with author). See also supra note 103 (clinics operate at Rwandan law schools, where the official language is now English, but French is still widely spoken in professional, commercial and government sectors.). To the extent it is important for prospective clinicians to look for support and guidance from peer institutions, the University of Lomé should develop a working relationship with the francophone faculty in Rwanda or Morocco. While there are a limited number of American clinicians who are proficient in French, some of the Canadian law schools have established French-language clinical curricula and programmes. See, e.g., https://capsuleweb.ulaval.ca/pls/etprod7/bwckctlg.p_disp_course_detail?cat_term_in $=201001 \&$ subj_ code_in=DRT\&crse_numb_in=2206 (service juridique offered for "university community" at Université Laval) (last visited $\overline{2}$ Aug. 2010); http://www.droit.umontreal.ca/baccalaureat_droit/FormationPratique.html (similar clinical offering under the rubric of formation pratique at the Université de Montréal)(last visited 2 Aug. 2010); and http://mlic.mcgill.ca/CIJM.html (McGill University's bilingual clinique d'information juridique)(last visited 9 Aug. 2010). 
interaction or opportunities for formation pratique. ${ }^{116}$

Upon further working group discussion, it became apparent that students who enter the faculty of law right out of secondary school may have too little background or professional orientation at that stage to fully participate in a legal clinic designed for would-be lawyers. ${ }^{117}$ This viewpoint has been echoed by other scholars in the field. Professor Frank Bloch, an active GAJE member, has previously observed that a clinical programme for an upper teen at an undergraduate college of law in a "lecture-based, code-dominated curriculum" may look different than it does for his American law school counterpart. According to Bloch, the American student tends to be older, desirous of a career in the legal field and engaged in an "interactive and advocacy-oriented course of study." 118 Professor Kirsten Dauphinais notes other ways in which African law students may be unprepared to adopt some of the American innovations. ${ }^{119}$

One must adopt a model that is compatible not only with national legal institutions and practices, but also with the educational system. Professor Leah Wortham, a veteran clinician in the international arena, goes further with her sage advice that American consultants not be wedded to their "home country model" of what constitutes a law school clinic. ${ }^{120}$ Professor Richard Wilson has devised a ten-step program in clinic construction, complete with five foundational

116 See, Geraghty \& Quensah, supra note 14 at 90, 97, 100 and Dauphinais, supra note 10 at 67-69, 91.

117 This point was reinforced in conversations I had with faculty and others on subsequent programme visits to the Universities of Dschang, Yaoundé, Maoura and N'gaoundéré, in Cameroon.

118 Bloch, supra note 31 at 115 . But see, Hovhannisian, supra note 82 at 15 (European universities that enrol students in law faculties just after secondary school now recognise the need for "practical training at the early stages of legal education") and James Marson, Adam Wilson \& Mark Van Hoorebeak, The Necessity of Clinical Legal Education in University Law Schools: A UK Perspective, INT'L J. Clin. Legal Ed. 29, 41-42 (Aug. 2005) (noting appropriateness of clinics at undergraduate level).

119 Being accustomed to overly formalistic, theoretically-based teaching is only one barrier. Students may come to the university from resource-poor secondary schools. English (or French) may well be a second, third or fourth language and students from diverse backgrounds may have had little cross-cultural interaction before they begin their tertiary education. Dauphinais, supra note 10 at 95 . The challenge is also "teaching students in an educational culture that is not student-centered, that is lecture-based, and that favors passivity and deference..." Id. See also, Geraghty \& Quensah, supra note 14 at 100 (warning that "pervasive politeness" of African law students not be mistaken for enthusiasm for interactive teaching methods).

120 Wortham, supra note 6 at 670-74. Wortham, however, seems to discourage the practicum or externship model as bona fide clinical education. Id. at 660. But see, Geraghty \& Quensah, supra note 14 at 100 (qualifying "carefully supervised student externships" in government agencies, NGOs, and human rights organisations as a "clinical" model) Wortham, supra note 6 at 670-74. Wortham, however, seems to discourage the practicum or externship model as bona fide clinical education. Id. at 660. But see, Geraghty \& Quensah, supra note 14 at 100 (qualifying "carefully supervised student externships" in government agencies, NGOs, and human rights organisations as a "clinical" model) Id. at 2.Pedagogically, financially and/or logistically, the leap to an in-house clinic may be just too great for some institutions - at least in the initial stages of experimenting with experiential education. The externship or field placement has evolved into a more robust and credible vehicle for learning and practice, thanks to efforts by the American Bar Association and by a number of able law school professionals and academics - including Professor Wortham herself. See, e.g., ABA Standards and Rules of Procedure for Approval of Law Schools, Standard 305 (Study Outside the Classroom), avail. at http://www.americanbar.org/groups/legal_ education/resources/standards.html (last visited 21 Nov. 2011). See also, Learning From Practice (J.P.Ogilvy, Leah Wortham \& Lisa G. Lerman, Eds.) (2d ed. 2007) (textbook used in a number of U.S. law schools for extern students' classroom component). On the other hand, Professor Dauphinais points out that " $[t]$ he average African law firm is small and often poorly organized" and experienced lawyers may be "too busy to assist in the development and training of the young lawyers" and "may merely perpetuate the relatively low standards of old." Dauphinais, supra note 10 at 91-92. This critique is familiar to externship detractors. But see, Ojienda \& Odour, supra note 70 at 56-57(externships utilised, together with classroom simulations, to give students clinical experience that is otherwise absent in law school curriculum). 
principles. ${ }^{121}$

Although the working group had not raised the issue, I knew from past experience and research that funding the clinic could also prove to be a huge hurdle. The American government's expectation is that the host government or academic institution will commit its own resources to a clinic, and not rely exclusively on the United States or other foreign donors. Togo was not in a position to easily allocate such funds. ${ }^{122}$ As I listened, I was pleased with the direction of the discourse, as these were themes I had promoted earlier in the week. But, as a foreign advisor and non-Togolese jurist, I was wary of steering the group toward a predetermined conclusion, rather than allowing the Togolese to organically develop and nurture their own proposals.

\section{4e Jour}

The final plenary of the symposium was devoted to reports from the working groups. ${ }^{123}$ Members of Group One proposed the adoption of an executive order or décret to implement the existing indigent assistance statute, Article 10, by laying out a definition of legal aid, conditions of access and limitations. Even in this proposal there remained a near obsession with the failure of the Executive to implement the statute's spare but precise text for almost three decades. It was as if until the decree were issued and the bureaucratic machinery cranked up, no legal assistance could be offered the poor. On the other hand, the Executive delay might be considered reasonable in light of the Constitutional separation of powers between the independent judiciary and the Government. ${ }^{124}$ Under this framework, action by the executive branch to implement judicial guarantees such as access to the courts, might conceivably be viewed as interference. This tension may well explain the stagnation of the law, even in light of a democratic transition in Togo.

Group One also called for the installation of orientation and assistance booths in all Togolese courts. The group advocated for promotion and reinforcement of the role played by the bench

121 Wilson, supra note 85. Under Wilson's definition of a clinic, it must be part of the law school curriculum, offered for credit, and be accompanied by a course using experiential methodology. Its students should be engaged in actual cases or projects, supervised by experienced attorneys, on behalf of clients who may otherwise go unrepresented. Professor Iya, writes, supra note 65 at 18, that clinical education in Africa may be called "skills training" or "professional training." These are concepts that tend to be devalued by American purist clinicians, as well as doctrinal law faculty. The former view them as a diluted form of the live-client, intensive supervision and reflective lawyering experience, and the latter dislike the trade school connotation. For an overview of how African clinical models draw on professional skills training and simulation and writing exercises to complement live-client representation, see, e.g., Dauphinais, supra note 10 at 93-94, 111-13 and Ojienda and Odour, supra note 70 at $53-56$.

122 Funding, and particularly local funding, will be a constant concern. The small faculty-student ratio inherent in most clinical programmes is reason enough to ask how can one expect African law schools to invest in what their American counterparts continue to view as an expensive educational venture? Geraghty \& Quensah, supra note 14 at 102 . In an important display of solidarity and continental self-determination, the African Union (AU) has urged richer African nations to regularly fund higher education in poorer nations where internal and other sources were not available. AU, Second Decade of Education for Africa (2006-2015) Plan of Action, Revised at 2 (Aug. 2006), avail. at http://www.education.nairobi-unesco.org/PDFs/Second\%20Decade\%CC20of\%CC20Ed ucation \%CC20in\%Cr ica_Plan\%20of\%20Action.pdf (cited in Geraghty \& Quensah, supra note 14 at 96, n. 52). This is not likely to lead to overflowing coffers any time soon. Hence, the "call for action" for the philanthropic and academic communities to fund personnel and infrastructure and otherwise support innovative, revitalized African legal education. Id. at 104. See also, Dauphinais, supra note 10 at 95, n. $233 \& 120$ (limited public funding and other resource constraints in African law schools).

123 Rapport Général du Seminaire, supra note 59 at 9-10.

124 Sama, supra note 72 at 161. 
and bar. This approach would include legal aid programmes based in law faculties. These innovations could truly foster a pro bono ethic, building on the current bénévolat and annual visits by lawyers to the prisons. ${ }^{125}$ It could also give meaning to the recently adopted protocol between the Lomé bar and the law school.

Group Two proposed similar changes. It called for a training programme, with theoretical and practical emphases, as an elective at the judicial college and faculty of law. The theoretical curriculum would focus on conceptual definitions, ethical norms, legal foundations, interuniversity exchanges and alternative methods of conflict resolution. The practical programme would concentrate on statutory amendments [redaction d'actes], "drop-in and orientation" centres and legal clinics, ${ }^{126}$ and reliance on paralegals. ${ }^{127}$ The objective, the group's members said, was to give future attorneys and judges the necessary tools to familiarise citizens with their rights and facilitate their access to justice. When other seminar participants expressed some concern about the clinic proposal, the working group responded that its mandate was to suggest a general orientation about instilling a "legal aid consciousness," while leaving it to the University to determine the practical methods of teaching the subject matter. ${ }^{128}$

125 In countries without large law firms, a central agency, such as a bar association, may assign cases to pro bono attorney members. Geraghty et al., supra note 37 at 80 . However, under such schemes, assignments often fall to young and inexperienced lawyers. To develop a more effective model for delivering legal aid, even with financing challenges, the ABA Rule of Law Initiative partnered with the Moroccan Federation of Young Lawyers and the Rabat Bar Association to organise a study tour for six prominent Moroccan lawyers. https://www.abanet.org/ rol/news/news_morocco_new_legal_aid_model_0110.shtml (last visited 26 June 2010). Of course, a new lawyer's eagerness and earnestness should not be discounted. One West African commentator observes that the "new wigs" may even wait in the courtroom for cases to be assigned to them, a sign of "their disposition to provide legal assistance to desperate defendants." Sama, supra note 72 at 157.

126 According to Professor Wilson, “...[A] law school can call its clinical legal education program by any name - live-client clinic, legal aid, field placement (externship or internship), street law, simulation or role-play, apprenticeship or any other local name - so long as the focus is on student experiential learning - learning by doing - for academic credit." Wilson, supra note 11 at 829 . Professor Bloch asserts that "access to justice" is a "central component" of clinical education in the U.S. and abroad. See, Bloch, supra note 31 at 111 \& n. 1 (citing sources that document role law school clinical programmes play in assuring equal access to law and the legal system). The three key elements of clinical education, according to Bloch, are: "professional skills training, experiential learning, and instilling professional values of public responsibility and social justice." Id. at 121 . See, Appendix II, A Bleuprint [sic] for a Francophone African Law School Clinic.

127 On the current use of paralegals and non-lawyers in African legal regimes, see Geraghty et al., supra note 37 at 53; Stapleton, supra note 3 at 20. David McQuoid-Mason, The Supply Side: The Role of lawyers in the Provision of Legal Aid - Some Lessons from South Africa, id. at 97. See also, David McQuoid-Mason, "Pro Bono Work by the Legal Profession and Clinical Legal Education" (powerpoint, n.d.) (on file with author); Iya, supra note 65 at 19 (clinical programmes used to train paralegals); and Stephen A. Rosenbaum, The Juris Doctor is In: Making Room at Law School for Paraprofessional Partners, 75 TENN. L. REV. 315 (2008) (urging law schools to co-educate future lawyers and future lay advocates and paralegals).

128 The skepticism about clinical methodology expressed by the Togolese bar and academics might also resonate with American clinicians who have a fine-tuned sense of what is fundamental to a clinic. As noted above, the Projet Clinique Juridique Berkeley-Goma, in trying to launch a law school clinic for women survivors of genderbased violence, had to temper its ideas about programme content, service delivery and objectives - even on what might be considered the essentials - when reconciling its proposal with the one conceived by the Goma-based law faculty and NGO. Flexibility is the byword of veteran international clinicians Bloch, Wilson and Wortham when it comes to designing the appropriate model. See, supra notes 120-21,126 and accompanying text. Professor Jessup also reminds us that "[a]lthough the American experience is informative and may provide guidance to an African law school contemplating a clinical program, it is imperative that any attempt to incorporate a clinical experience into a current African law school curriculum take into account a cognizance of the political structure of governmental organizations and customary norms. [footnotes omitted].” Jessup, supra note 84 at 380. 
Before the closing ceremony, those assembled adopted the recommendations of both working groups in a final report. ${ }^{129}$ The session adjourned and we abandoned the air-conditioned hotel meeting room for the hot, dry, late afternoon air. Participants completed twenty evaluation forms and returned them to the Embassy staff.

With the exception of remarks about hardship associated with travel to the site, the comments were all positive in endorsing the seminar themes and recommendations. When asked to name three ideas they retained from the seminar for use in their professional life, many referred to the concept of practical legal education, including: cliniques juridiques, externships for upper-level law students, and fostering a legal aid ethic in the curriculum offered at the law faculty and the Ecole Nationale de la Magistrature. Others referenced the need to finally implement Article 10, create a legal aid funding scheme, establish a pro bono programme, and to set affordable attorneys' fees for clients. Another mentioned increased utilization of paralegals and more know-your-rights outreach to the public about legal assistance. One participant liked the comparative law perspective. ${ }^{130}$

As for suggestions for the future, respondents indicated that more such practice-orientated continuing education seminars should be held. They urged expanding participation to bailiffs, marshals, clerks, notaries, law students, judicial college students, senior attorneys, the human rights minister, and members of civil society and non-governmental organizations. Rather than restrict such gatherings to the capital, participants urged that seminars be held in other cities throughout the country and that they be open to the media. Another respondent was anxious to see positive effects from the group's recommendations and produce the fruits of their labour ("produire leurs fruits") in a reasonable amount of time. In the same vein, another voiced concern that the work product not collect dust in file cabinets ("classés dans des tiroirs"). ${ }^{131}$

Before planning the next steps, the coordinators and a small group of participants celebrated the close of the program at a dinner at the home of Maître Attoh-Mensah. An established member of the bar who supports human rights causes and appeared to share the aims of the seminar, Attoh-Mensah had previously traveled to the United States on State Department legal reform exchanges. ${ }^{132}$ The Chair of National Human Rights Commission, ${ }^{133}$ Koffi Kounté was among the guests. One of my Embassy hosts had informed me that he had a genuine concern about prisoners

129 Rapport Général du Seminaire, supra note 59 at 10.

130 Fiches d'Evaluation (on file with author).

$131 \mathrm{Id}$.

$132 \mathrm{Me}$. Attoh-Mensah and his counterparts in other African nations are the kind of informal leaders who could be influential in promoting new legal initiatives. They could also just as easily be dismissed as privileged blowhards or junket seekers - or even what Dean Garth, supra note 16 at 396, calls the "cosmopolitan elite" whose objectives are focused more on self-aggrandizement and economic or political gain than socio-juridical improvements. In her evaluative toolkit for funding legal clinics, Professor Wortham reserves a large space for testing the "competence, sincerity and integrity" of those involved. Wortham, supra note 6 at 669 . Although a challenging trait to measure, the advice is equally apt for funding any start-up. Wortham suggests relying on locals to evaluate and to do over time, and in multiple settings. Id. at 669-70.

133 Constitution de la République Togolaise, art. 133 (creation of the Commission Nationale des Droits de l'Homme, an independent national human rights commission). 
with mental illness. ${ }^{134} \mathrm{He}$ struck me as someone in a position of responsibility with whom I should have some follow-up contact about treatment of detainees. We exchanged email addresses. We talked about the delays in processing prisoner cases ${ }^{135}$ and how this was particularly detrimental for mentally ill detainees. I suggested that student or postgraduate stagiares ${ }^{136}$ might help judges alleviate their docket.

He seemed a bit skeptical at the prospect of anyone but the judge actually managing a case. To me, however, encouraging the judiciary to utilize students is merely a variation on the larger effort to convince the bar to supervise and train its future members.

We continued our informal conversations over a meal served in a gated courtyard under the stars, with no particular agenda and no need for decision making. It is important to have this type of meeting with prospective reformers, outside of formal settings. There is more opportunity for candor and reiteration. This is particularly the case where the conference is long on theory and short on pragmatics. For real change to take place, we must develop interpersonal relationships to build confidence and to continue the dialogue once the seminar banner is packed away. I regret that I am not always able to maintain these contacts upon departure or to monitor progress on proposed reforms.

\section{5e Jour}

The Bar Association devoted the day after the seminar to a presentation of the conclusions and recommendations to the full bar membership and the media. I shared the podium that morning in a darkened hall at the Bar Association headquarters, with the Bar's programme coordinator, Maître Afangbedji, who also served as liaison to the Embassy. ${ }^{137}$ The auditorium was full. I recognised very few people from the seminar, and I was uncertain who in this crowd was an attorney, a journalist, a government official or a NGO activist.

Me. Afangbedji and I each spoke briefly about the recommendations made at the close of the Ghis Palace conference concerning legal aid, voluntary lawyer services and legal education. We

134 African prison conditions, including treatment of mentally ill prisoners, is the subject of two extensive human rights declarations issued after pan-African conferences held in the past several years. The declarations are laden with all the right words, just waiting to be given meaning. See infra notes 135, 141- 45, 149-51 and accompanying text. As mental health law and disability rights are some of the subjects I teach, I have a particular interest in the sub-population of incarcerated persons with mental disabilities. I also worked as a staff attorney for a disability civil rights NGO for over a decade, although I have not traveled to Africa in that capacity.

135 Notwithstanding statutory and constitutional guarantees, delay in the judicial processing of pretrial detainees is the norm in a number of countries. See, e.g., Rebuilding Courts and Trust, supra note 109 at 22 (up to $75 \%$ of Congolese detainees were awaiting trial in 2009) and Federica Dell'Amico, The Impact on Prisons: Overview of Problems Leading to High Prison Overcrowding, in Access to Justice in Africa, supra note 3 at 297, 299-300 (inefficiency of criminal justice system). See also, Kampala Declaration on Prison Conditions in Africa (1996) (hereafter, Kampala Declaration) reprinted in Access to Justice in Africa (recommending that judiciary ensure prisoners are kept in remand detention for "the shortest possible period" with regular review), reprinted in id. at 223; and Ouagadougou Plan of Action (on Accelerating Prison and Penal Reform in Africa (2002)) (hereafter, Ouagadougou Plan of Action)(recommending speedy processing of trials by police, prison services and courts and reduced delays of remand detention), reprinted in id. at 234. These declarations and plans of action, along with other related texts, are also available at http://www.penalreform.org (last visited 16 July 2010).

136 This translates as "apprentices," "externs," "interns" or "pupil-lawyers."

137 Maître Gil-Benoît Afangbedji, Ordre des Avocats, Lomé. 
referenced the Lomé bar association-law school protocol signed earlier that year. ${ }^{138}$ What neither of us noted is that in establishing a law school clinical programme of any sort, the temptation is to rely on members of the private bar or an NGO-affiliated attorney, as they have more practical knowledge and experience than the professoriat. For long-term sustainability, however, it is necessary to have law faculty involvement. ${ }^{139}$

Questions and comments followed. Most of the audience comments focused on the role of paralegals, law student clinics and student externships. More than one lawyer expressed skepticism about this advocacy model. Their concern generally centered on competition for clients, professional integrity or both. ${ }^{140}$ Bar associations in many countries tend to be ingrown and protectionist, with controlled access to membership. Although small in numbers, the Togolese bar is no less concerned than its counterparts in developed countries about non-lawyers giving advice and counsel. ${ }^{141}$

In addition to asking about the programme, members of the media also asked about the United States' human rights record at home. These questions are typical of the inquiries made to official visitors. Reporters and others asked about the death penalty and its uneven application across the states, the status of Guantánamo Bay detainees, police abuse and racism. Although embassy staff during other program visits have sometimes tried to shield me from impertinent or provocative questions, I did not feel the need to censor my answers. In fact, I believe these issues merit discussion even in the context of a ROL conference, in part because a government that is promoting democratisation and celebrating civil society and rule of law must bare its own account. Accordingly, journalists often take advantage of the opportunity to question an American visitor even if these are not the topics on the speaker's menu du jour.

After the press conference and some individual TV and radio interviews, I walked down a long unpaved road with a group of lawyers, in the late morning heat, to one of the principal prisons in Lomé. Most of these lawyers were newer members of the bar, including stagiares, and had attended the Ghis Palace seminar. I am not sure if the trip to the prison was impromptu or anticipated, but I was glad for the chance to have a personal observation of the prospective clients whose prolonged detention prompted the renewed call for legal assistance.

About eight to ten of us entered a dusty prison yard in our suits and ties. The scene before us was overflowing with humanity, and yet a degree of normalcy, as if all the hot, sweaty, teeming life of the streets and shanty towns was transported to this sunny open, but densely populated space. I saw only a few uniformed guards, and they did not carry weapons. Near the entry, a plainly lettered sign had been posted by the European Union ${ }^{142}$ with the number of current detainees-a number

138 Protocole de Partenariat, supra note 34.

139 Wortham, supra note 6 at 669. Professor Maisel's colleagues in South Africa agree that the campus leadership must share the clinical vision. Maisel, supra note 16 at 487-88.

140 The same comments have been made by private lawyers and bar associations in the West and elsewhere in Africa. See, e.g., Rosenbaum, supra note 127 at 322-23 (U.S. attorneys and bar associations voice concern about inexperienced, untrained and/or unsupervised lay advocates) and Open Society Institute, supra note 101 at 24 (concern of private lawyers in Kenya).

141 Wortham, supra note 6 at 662 .

142 The European Union has helped support the pan-African conferences on penal reform has had an on-going interest in detention and incarceration practices in African countries that are recipients of EU assistance. See, e.g, http://allafrica.com/stories/200809080090.html (last visited 16 July 2010) (human rights training for Ugandan prison officials). 
I do not recall. Was this meant to assure monitors and visitors, or was it displayed as a proud banner, to see how Togo ranks on the overcrowding scale with its neighbours on the continent? ${ }^{143}$

The prison yard was a picture of petit commerce, visiting, the biding of time. It was at once industrious and carefree. Off to the sides were dark caves of cells filled with thin mats, and walls hung with laundry and personal effects. There were no bars on the cells. Masses of shirtless men and boys were talking, sitting, lying down, selling, buying. We came as sympathetic observers, and yet it was hard not to feel like voyeurs.

The Kampala Plan of Action, which followed the 1996 Conference on Prison Conditions in Africa, recommends educational activities, skills-based training and a work programme, incorporating elements of self-sufficiency and sustainability. ${ }^{144}$ The 2002 Ouagadougou Plan of Action recommends nationally certified vocational training, rehabilitation and development programmes, with ensured access for "unsentenced" prisoners, literacy and skills training. ${ }^{145}$ The latter plan also calls for more self-sufficient prisons by fostering prison agriculture, workshops, locallymanaged industries and other enterprises "for the good of prisoners and staff." 146 None of that was happening here.

Chez les femmes, the women's section, revealed a slightly different story. The handful of incarcerated women (and one or more with a child) were actually separated from the men. Throughout the world, women are a minority of the prison population, but their numbers are increasing. According to Penal Reform International, the increase is "fueling the global trend" toward overuse of imprisonment and under-use of alternative sanctions. ${ }^{147}$ At the Lomé prison, their quarters were more spacious than the men's. They were almost homey in a modest way. Not all was out of sync with the lofty declarations and plans of action: the staff proudly showed us how

143 See, e.g., Rebuilding Courts and Trust, supra note 109 at 22 (in DRC, cells are overpopulated, minors not segregated from adults and pretrial detainees are not separated from convicted criminals); Sama, supra note 72 at 155 (overcrowding and unsanitary conditions in Cameroon, where "vulnerable groups like women, women with babies, juveniles, the elderly, and terminally ill" are amongst the long-term pretrial detainees). As noted above, three pan-African conferences held since 1996, have resulted in declarations and plans of action aimed at eradicating long-term detention and unsanitary and desultory prison conditions. In addition to the Declarations of Kampala and Ouagadougou, supra note 135, the Lilongwe Declaration and Plan of Action also address legal aid to prisoners. See, Lilongwe Plan of Action, supra note 32 at 48-49 (better judicial processing of detention cases, more use of paralegal services, easier access to prisons by NGOs, community-based organisations and faith-based groups). The comparison with advocacy efforts in the United States to eliminate prison overcrowding and impove health care is a bit surreal, given the contrasting conditions and standards. See, e.g., Brown v. Plata, _U.S._, 131 S.Ct. 1910 (2011) (affirming lower court order that State of California must substantially reduce prison population due to overcrowding); Coleman v. Wilson, 912 F.Supp. 1282 (E.D. Cal. 1995) (mandating overhaul of prison mental health system).

144 Kampala Plan of Action on Prison Conditions in Africa, reprinted in Access to Justice in Africa, supra note 3 at 226. Many prisoners require only minimal security and "should be accommodated in open institutions." The incarcerated should involve themselves in "educational and productive activitie with the support of staff." Id. at 228.

145 Id. at 235.

146 Id. In addition, the United Nations adopted a set of "minimum rules" for treatment of prisoners in 1957 and another set of rules in 1990 for non-custodial measures for pretrial detainees, as well as principles for the protection of all detained and imprisoned purposes (1988). These are available at http://www.un.org/disarmament/convarms/ ATTPrepCom/Background\%20documents/CompendiumofUnstandardsandnormsincrimeprevention.pdf.

147 See Penal Reform Briefing No. 3 (2008)(1), avail. at (http://www.penalreform.org/publications/penal-reformbriefing-no3-women-prison-0 (last visited 19 Dec. 2010). The largest numbers of incarcerated women are actually in the U.S., Russia and Thailand. Id. 
some of the women were learning to sew as an eventual trade.

We were told there was a woman prisoner with a mental disability. "C'est une folle."148 I do not remember if I caught a glimpse of her, isolated in a dark cell, or if there were just the whispers. On the subject of mentally ill prisoners, the Kampala and Ouagadougou conferences yielded some broad legal standards. The Kampala Declaration and Plan of Action, for instance, urge the adoption of "urgent and concrete measures" to improve conditions for persons with mental illness and disabilities, including adequate treatment during arrest, trial and detention, and that access to doctors be allowed. ${ }^{149}$ The subsequent Ouagadougou action plan recommends prison alternatives for people with "mental health or addiction problems;" and social and psychological support by professionals. ${ }^{150}$

Yet, there we were, witnessing what we and other legal reformers in Africa hoped to alleviate. It is possible that "sidebar" conversations were taking place outside of earshot, and the attorneys accompanying me were able to process minor cases on the spot, helping to clear the backlog of pretrial detainees. Surely, that is what happens during the periodic journées de consultation juridique gratuite. Could those free consultation days be institutionalized through a routine bar association pro bono programme? Could a law student clinic assist those lawyers or help train paralegals, or provide community education and outreach to families, street merchants, secondary school students, rural villagers and others? ${ }^{151}$ Could law students serve as externs to magistrates to help them clear the detention backlog? A few small and creative steps could begin to breathe life into the promises embedded in a plethora of declarations, action plans, minimum standards, principles, statutes and constitutions.

\section{6e Jour}

As disability rights is the bread-and-butter of my law practise in the United States, I try to find ways to make some connection to the local disability community on these speaker specialist

148 "It's a crazy woman."

149 See, Kampala Declaration, supra note 135 at 222, and Plan of Action, id. at 227. The Declaration also recommends that non-custodial measures be used in lieu of imprisonment. Id. at 225.

150 See Ouagadougou Plan of Action, id at $233 \& 235$. One of the Ouagadougou Declaration's principles is that governments recognise they are ultimately responsible for ensuring "prisoners can live in dignity and health." Id. at 232 .

151 See, Lilongwe Plan of Action, supra note 32 at 49 (encouraging governments to establish prison paralegal services to assist with bail and release, prisoner legal education and self-help, appeals and special assistance to vulnerable groups). A few months before my visit to Lomé, the Embassy published a guide on the rights of detainees. "Le Nouveau Guide des Droits du Détenu Remis aux Autorités," USA-Togo: Bulletin d'Information de l'Ambassade des Etats-Unis au Togo 12 (Jan.-June 2007) (on file with author). 
visits. ${ }^{152}$ The best I managed during my stay in Togo was a Saturday morning excursion to the local marketplace, where my penchant for local artisanry brought me in contact with an organisation supporting people with disabilities. Located in the rural northern zone of Togo, the Coopérative des Handicapés de Niamtougou (CODHANI) is composed of persons with physical impairments who produce crafts for sale in the capital and abroad. Its goal is to improve living conditions for disabled persons and support their social and economic integration into society. ${ }^{153}$ I found CODHANI's shop in Lomé, after wandering through a warren of vendors-fabrics, spices, potions, ceramics, household goods-with the help of an Embassy aide and after many inquiries for directions.

In the constellation of recognised human rights, those associated with disability are among the most recently established. ${ }^{154}$ In 2005, Togo enacted a law prohibiting discrimination against persons with disabilities in employment, education and access to health care and government services, but, according to the State Department, it is not "effectively enforce[d]." 155 While I would have preferred contact with an advocacy or service provider NGO, I was pleased to purchase colourful tie-dyed fabrics made by and for the economic benefit of individuals with disabilities.

\section{Post-Script}

The tape that keeps playing in my head throughout this and other visits goes something like: Les conferences, les entretiens, les visites. The lectures, the meetings, the visits. A quoi ca sert, tout ca? What is it all about? ${ }^{156}$ In the end, it may be simply about a beginning: Perhaps an opportunity for dialogue - between visitor and hosting jurists, or amongst local jurists who rarely get together

152 On a subsequent trip to Africa, the Embassy arranged a visit to the modest headquarters of Goodwill Cameroun, a national multi-disability services and advocacy organisation based in the capital, Yaoundé. It was evident at the time of our meeting - and more so in email exchanges with Goodwill's president since then - that even a brief dialogue with a foreign visitor who understands disability issues is an act of immeasurable solidarity and support for a NGO. Rapport de Visite à Goodwill-Cameroun (2009)(on file with author.) A year later, the U.S. Cultural Affairs Officer in Dakar asked if I would meet with a federation of disability rights NGOs. "It's such an under-served population in Senegal," she wrote. "I hope that's not too far off field to ask you to meet with them, but we noticed in your CV that this is also one of your areas of expertise." (Email of 13 Sept. 2010 from Kristin Stewart) (on file with author). The irony in this request was not only the Embassy's off-handed discovery of my primary field of legal expertise, but that management staff at my law office, Disability Rights California, saw little value in my work in Africa, which they considered a distraction from their organisational mission).

153 See, http://www.facebook.com/pages/Coop\%C3\%A9rative-des-Handicap\%C3\%A9s-de-Niamtougou/1596180 54050727\#!pages/Coop\%C3\%A9rative-des-Handicap\%c3\%A9s-de-Niamtougou/1596180540727?v=info_edit_ sections (last visited 12 Nov. 2011).

154 See, e.g., United Nations Convention on the Rights of Persons with Disabilities.http://www.un.org/disabilities. Almost one year after my visit, Togo signed the Convention and Optional Protocol, in 2008 and, unlike the United States, it ratified the treaty and protocol in 2011. http://www.un.org/disabilities/countries. asp? navid=12\&pid=166\#T (last visited 12 Nov. 2011). See also, United Nations Office on Drugs and Crime, http://www.unodc.org/unodc/en/justice-and-prison-reform/index.html?ref=menuside (last visited 16 July 2010)

155 U.S. Dep't of State, Country Reports on Human Rights Practices, supra note 8. "There was no overt state discrimination against persons with disabilities, and some held government positions, but societal discrimination against persons with disabilities was a problem....Although the law nominally obliged the government to aid persons with disabilities and shelter them from social injustice, the government provided only limited assistance." Id.

156 The English does not quite capture the meaning: What is it all about? What is the point in all this? 
in the absence of an outside visitor. ${ }^{157}$

It goes without saying that short-term visits and short-term foreign visitors have their limitations. ${ }^{158}$ I knew before I left Berkeley that I could not will the establishment of a law school clinic or a volunteer legal services programme in Togo in one week. Nor one semester. Perhaps not even in one year. The logistical and cultural gaps are huge. The successful establishment of any new program or institution takes time and it takes others. There must be more face-to-face exchanges and of longer duration. There must be a greater interchange between Togolese who study, observe, teach or consult abroad - in Africa, Europe or the United States - in law school, law practice or NGO settings, and foreigners who come to Togo to do the same. Any attempt at establishing a clinical system will also require public and private funds, administrative and technical feasibility, and political will.

The key for the consultant is to encourage trends or the creation of a new legal or socio-political culture in a way that does not trigger a divisive response. The question from our host country partners should not be: "How can a pays en voie de developpement - or, the Global South - be expected to adopt the measures and practices that are available to a pays developpé?" This question misses the mark, because the efforts at issue are not a prescription for establishing relativist standards, but a recognition that a country with fewer resources will have to husband those resources for higher priorities.

In the same vein, one must strive to impart information and exchange ideas in a spirit of mutual respect, and not by way of the sermon or financial carrot-and-stick. Would-be clinical instructors and bar association activists in Togo, or elsewhere, must not feel overwhelmed or demoralized by the knowledge that arguably "better" policies or customs are in place in the United States in the establishment of law school clinics and pro bono programmes.

Instead, the process of creating a clinical programme and pro bono system is all about the encouragement of what is possible within the existing legal, political, socio-cultural and economic frameworks. The visitor then leaves behind a little reflection and self-criticism, a little passion, some commitment, a lot of goodwill and solidarity - and asks for the same in return.

Je vous remercie de votre attention.

157 After working in a rule of law partnership with a Haitian law school for over a decade, utilising what he terms a "slow law" approach (akin to the "slow food" movement), Professor Richard Boswell cautions against setting a certain set of outcomes or deliverables. Have "no expectations" about results, he told an audience recently at the University of California, Berkeley School of Law. (Annual Stefan A. Reisenfeld Symposium: "Justice Under Construction," 31 Mar. 2011).

158 Professor Wortham's criticism of the "drop in” foreign expert lecture approach to effecting change is well-taken. Wortham, supra note 6 at 677 . The efforts simply cannot begin and end there. 


\section{APPENDIX I}

\section{Seven ${ }^{159}$ Tips for the Short-Term Consultant}

1. Do not expect the Embassy to lay out a clear agenda - beyond an itinerary of activities - or to have answers to all your questions before you arrive. Be flexible.

2. Do not be afraid to set your own objectives for the visit and its aftermath. Be flexible.

3. Dispense some theoretical knowledge about American law and practices to the extent it meets your hosts needs and do some homework on your own before you embark or while on your visit.

4. "Whet the appetite" of your audience. Be charming and gracious.

5. Make the most of the intellectual and cultural exchange. Be humble enough to know that you too can learn much about your own country by working with another. ${ }^{160}$

6. As you meet with various players, gauge the local or national support for any idea or practice you propose. ${ }^{161}$

7. If your visit is to have any impact, follow-up is essential:

a. If not asked outright, seek opportunities to advise the relevant embassy staff on where to allocate U.S. funds or other resources. ${ }^{162}$

b. Keep non-U.S. public funding and other resourcing needs in mind with any particular proposal, i.e., NGOs and foundations, United Nations, European Union and individual European governments 163 - and do not discount what the host country must allocate at a

159 There is nothing talismanic - or even Kabbalistic - about the number seven. I offer apologies to Thomas Carothers for advice based heavily on personal experience, although dispensed through the lens of a practitioner "engaged in democracy aid" and not an academic "engaged in democracy theory." Thomas Carothers, supra note 14 at 93-94 (decrying reliance of earlier ROL and LDM "foot soldiers" on personal experience rather than on research)

160 Wortham, supra note 6 at 675.

161 One of the cultural challenges encountered in one-on-one conversations, particularly with key government officials, bar leaders and faculty members, is determining the degree of directness that is appropriate. Given the short time one has with interlocutors, it is tempting to make the most of it - even if not seeking an explicit commitment of time or resources, but perhaps a willingness to "move forward." Directness can be perceived by the host as brusque or impolite. The host may also have his own agenda or may not be in a position of authority to make any kind of commitment. What is a mere courtesy call and what is a working meeting? How senior is that lawyer or professor who seems to express genuine interest? These are the questions you will need to answer as you go, relying on embassy staff to the extent possible.

162 This does not mean U.S. financial assistance should be overlooked. See, e.g., State Department Request for Proposals: "Democracy, Human Rights and Rule of Law" to "build the capacity of the judicial sector to strengthen cognizance of and respect for the legal rights of individuals, especially detainees and those accused of crimes, with a special focus on increasing the use of bail (liberté provisoire)." http://www.state.gov/g/drl/p/130297. htm (last visited 13 Nov. 2009). The application process for this $\$ 500,000$ grant is full of possibilities and hurdles.

163 For example, Togo can count Germany as a reliable donor nation, due to its brief tenure as a colonial power before ceding the territory to France and Britain. During my visit, its Embassy gave a large garden party, to commemorate the unification of West and East Germany, where its still popular Togolese-bottled lager beer was in plentiful supply. 
national, agency or institutional level. ${ }^{164}$

c. Try to ensure future "working" exchanges of longer duration ( 3 to 6 months) by key actors:

i. U .S. teachers, lawyers, students and other consultants going to Africa; and

ii. Mid-level elites and junior associate African lawyers, (paraprofessionals), academics, and students coming to the United States: to teach, to advocate, to observe, to critique. $^{165}$

d. Promote local and regional contacts and networks within Africa.

e. Promote long-term personal relationships. ${ }^{166}$

164 Professors Geraghty and Quensah passionately advocate for an immediate and intensive investment of money and resources in African legal educational institutions. They call upon American academics and lawyers to aid their African peers in seeking funds and collaborating - with Africans in the lead - in the assessment and planning process. Geraghty \& Quensah, supra note 14 at 104-05. There are already some established sister school relationships between American schools and those in east and southern Africa. Dauphinais, supra note 10 at 84 , n. 183.

165 One informed commentator argues that (at least for launching a clinical educational programme) inviting wouldbe clinicians to the United States, to observe on-site for a period of time, is a far more useful expenditure of funds than sending a speaker abroad. Wortham, supra note 6 at 677 . Others have stressed the importance of collaborative and genuinely deferential relationships in establishing or improving local institutions. See, e.g. Dauphinais, supra note 10 at 105-06 (advocating co-authorship of curriculum materials and collaboration in teaching between African and American legal educators) and Maisel, supra note 16 at 489-90 (advising guest educator to come with lack of hubris, open agenda and ask how she can assist hosting colleague in transnational collaboration).

166 The importance of personal, ongoing relationships cannot be overstated. Wortham, supra note 6 at 676-77. Thomas Carothers' research reveals the overlooked psychological, moral and emotional support that a foreigner may bring, by showing interest in another country's problems and by returning and working with colleagues across borders. Thomas Carothers, Assessing Democratic Assistance: The Case of Romania (1996) 95-97 (cited in Wortham, supra note 6 at 678). Leah Wortham also recalls Carothers' comment that one should not assume valuable "psychological, attitudinal and educational" change occurs in every ROL or law and development project. Id. at 678, n. 279 (quoting Thomas Carothers, Aiding Democracy Abroad, 312-313 (1999)). 


\section{APPENDIX II}

\section{Bleuprint for a Francophone African Law School Clinic ${ }^{167}$}

\section{Synopsis:}

The goal of the Francophone Africa Law Project (FALP) is to establish a university-based legal aid clinic in francophone African countries that have adequate infrastructure, support and credibility. While such clinics currently exist in an increasing number of anglophone, common law African nations - usually where U.S. clinical law professors or NonGovernmental Organizations have taken the lead in providing technical assistance and funding - French-speaking Africa has been largely neglected.

\section{Introduction:}

a. U.S. law schools (with or without NGO support) are uniquely positioned to promote and nurture a clinique juridique. A by-product of this effort is a law student exchange programme.

b. A necessary component of the clinique juridique should include formalized bar associationlaw faculty collaboration in the designated country to develop a private bar pro bono culture and more integration of practitioners in local law faculties. Partnerships or other formalized relationships could be formed with local NGOs and/or customary law practitioners and decision-makers.

\section{Objectives:}

The first phase consists of a short-term field placement in which a limited number of U.S. students:

a. Enrol in classes in an African law faculty for one quarter or semester;

b. Observe trial and/or appellate court proceedings and customary or other informal dispute resolution practices on a regular basis;

c. Meet once or twice per week with lawyers, judges, court officers, government officials, law enforcement officers, elders or traditional leaders, students in law or magistrature, journalists and/or NGO activists;

d. Engage in limited, supervised, legal work (where possible);

e. Conduct an assessment of the potential for a clinique juridique, under the supervision of a U.S.-based clinician and practitioner and local NGOs.

167 In addition to Milliette Marcos, I thank Yvonne Troya and Charlotte Martinez for their contributions to this blueprint template for a clinique juridique typique, i.e.,a conventional law school (in-house) clinic. Assumptions about staffing and non-personnel expenses will obviously vary. See also, Wilson, supra note 85 . This should not necessarily be favoured over other approaches to fostering experiential or practice-orientated legal education. Adaptability and deference to local preference are essential. 
Future students would continue to build on the "needs assessment," with the eventual goal of setting up a fully functional clinic:

a. Funds permitting, United States practitioners and academics would also conduct periodic workshops or training modules on site, with assistance from their African counterparts (including jurists who return to their home country after obtaining an LLM);

b. American students would help to establish a long-term clinic and pro bono culture, and at the same time, benefit from an educational and multicultural experience, and forge future relationships with their African peers;

c. Ongoing participation by clinicians and practitioners would be dependent on funding;

d. Participating students must be fairly proficient in French and will need to secure their own funding for travel, accommodations and food;

e. The Project would assist in enrolment, on-site contacts, locating lodging and procuring visas.

\section{Selecting a University Pilot Project:}

University in chosen francophone country where the administrative, resource and legal commitments have been established and memorialized.

5. Prospective Partners (for funding, board of directors, advisory council, service delivery, etc.):

a. U.S. law school sponsor(s).

b. Open Society Justice Initiative. ${ }^{168}$

c. American Bar Association Rule of African Initiative / Africa Division. ${ }^{169}$

d. U.S. Department of State.

e. Global Alliance for Justice Education. ${ }^{170}$

f. AHEAD (African Higher Education Activities in Development).

g. African national and local bar associations.

h. Universities in other francophone countries in Europe and Africa.

i. Local chefs $d u$ village, chefs du quartier, sultans or other facilitators/adjudicators in traditional dispute resolution.

j. Other partners identified through a needs assessment (see below).

168 For details on this Soros Foundation Initiative, visit http://www.soros.org/initiatives/justice.

169 For details on programmes and opportunities, visit http://apps.americanbar.org/rol/africa

170 See supra note 31. 


\section{Structure:}

\section{Space:}

The university law faculty will house the administrative office of the law clinic. Most substantive and skills training will take place in classrooms at the university as well as community venues.

\section{Staffing:}

a. One full-time attorney Coordinator to act as Operations Manager. This Coordinator, in collaboration with African-based partners, will assist students in conducting a needs assessment, develop a training curriculum and establish effective delivery models.

b. One part-time African university professor to supervise the law school clinic students on-site and provide training for the clinic participants.

c. One part-time African staff attorney to collaborate with the University supervisor and the Coordinator.

d. One part-time clinic administrator for clerical, technical and logistical support.

\section{Time-Line:}

\section{Year " 1 "}

\section{a. 0-3 months:}

Selection and hiring of clinic staff.

Solicit applications from U.S. law exchange students.

Law students begin orientation.

Initiate Needs Assessment by surveying law school faculty and students, local bar association members, NGOs and other stakeholders. By coordinating with other local legal service providers, this needs assessment will ensure that legal services are not being duplicated.

Set up administrative offices at the university.

Engage in collaborative meetings with local bar association, judiciary, and government officials.

Create an Advisory Board of African and international members.

\section{b. 3-6 months:}

Complete needs assessment.

Develop training curriculum.

University law students submit applications to participate in the clinic. Participating students chosen based on interest and experience.

Invite African and international practitioners and clinicians for short-term training and exchanges on-site and abroad. 
Clarify role of local bar association members and recruit members and judges to mentor law students.

\section{c. 6-9 months:}

Law students begin clinical classroom component with emphasis on sensitisation, ethical training, skills-building and reflective lawyering.

Law students participate in substantive law training and mentorship.

Law students begin clinic work and begin preparing community education curriculum for both community members and medical providers. Law students will engage in other activities, including opening client cases, researching legal issues, meeting with their supervising attorneys.

African and international practitioners and clinicians participate on-site in short-term training and exchanges in classroom and clinical settings.

\section{d. 10-12 months:}

Conduct summary review of legal clinic progress to date, modify as necessary, and submit reports to funders.

\section{Years "2" \& “3”}

Continue development of classroom and training curriculum as needed.

Continue African and international practitioner and clinician short-term training and exchanges on-site and abroad.

Law students continue clinical classroom component, substantive law training and mentorship.

Law students continue working at clinics and conducting community education curriculum for community members.

Continue collaboration with local bar association, judiciary, and government officials.

Assess supervisory component and adjust as necessary.

Develop community education outreach materials for written or broadcast distribution.

Accept new and continuing law student applicants.

Incorporate U.S. law exchange student(s).

Collaborate with African and international practitioners and clinicians.

Develop lay advocacy component.

Conduct summary review of legal clinic progress to date, modify as necessary, and submit reports to funders.

\section{Costs:}

Salary of Coordinator, for years 1-2: $\$ / €$

Salary of university half-time administrator: $\$ / €$

Salary of university full-time supervisor: $\$ / €$ 
Salary of African half-time supervisor: $\$ / €$

Transportation, lodging and meal costs for student participants and presenters: $\$ / €$

Administrative costs (copying curriculum and community legal education materials): $\$ / €$

Translation/Interpretation fees: $\$ / €$

\section{Proposed project term and funding:}

Three years; $\$ / €$

\section{Potential Concerns:}

a. Will U.S. students enroll in African university as "exchange students" or will they participate for externship credit?

b. Who will provide the clinical classroom training?

c. How long will students from U.S. law schools spend in Africa? Is there a minimum requirement?

d. Will students have to be proficient in French? 